U.S. Investment in Global Bonds: As the Fed Pushes, Some EMEs Pull

John D. Burger, Rajeswari Sengupta, Francis E. Warnock, Veronica C. Warnock

Indira Gandhi Institute of Development Research, Mumbai January 2015

http://www.igidr.ac.in/pdf/publication/WP-2015-02.pdf 


\title{
U.S. Investment in Global Bonds: As the Fed Pushes, Some EMEs
}

Pull

\author{
John D. Burger, Rajeswari Sengupta, Francis E. Warnock, Veronica C. Warnock \\ Indira Gandhi Institute of Development Research (IGIDR) \\ General Arun Kumar Vaidya Marg \\ Goregaon (E), Mumbai- 400065, INDIA \\ Email(corresponding author): rajeswari@igidr.ac.in
}

\begin{abstract}
We analyze re-allocations within the international bond portfolios of US investors. The most striking empirical observation is a steady increase in US investors' allocations toward emerging market local currency bonds, unabated by the global financial crisis and accelerating in the post-crisis period. Part of the increase in EME allocations is associated with global "push" factors such as low US long-term interest rates and unconventional monetary policy as well as subdued risk aversion/expected volatility. But also evident is investor differentiation among EMEs, with the largest re-allocations going to those EMEs with strong macroeconomic fundamentals such as less volatile inflation and more positive current account balances.
\end{abstract}

Keywords: International investments, Local currency bonds, Portfolio reallocations, Macroeconomic fundamentals, Emerging economies

JEL Code: F3, F4, F6

\section{Acknowledgements:}

This paper has been released as NBER Working Paper No. 20571. Preliminary version of this paper was prepared for the 60th panel meeting of Economic Policy, October 2014. 


\title{
U.S. Investment in Global Bonds: As the Fed Pushes, Some EMEs Pull
}

\author{
John D. Burger \\ Sellinger School of Business, Loyola University Maryland \\ Rajeswari Sengupta \\ Indira Gandhi Institute of Development Research (IGIDR), Mumbai, India \\ Francis E. Warnock \\ Darden Business School, University of Virginia \\ Institute for International Integration Studies, Trinity College Dublin \\ Globalization and Monetary Policy Institute, Federal Reserve Bank of Dallas \\ NBER \\ Veronica Cacdac Warnock \\ Darden Business School, University of Virginia
}

January 2015

\begin{abstract}
We analyze reallocations within the international bond portfolios of US investors. The most striking empirical observation is a steady increase in US investors' allocations toward emerging market local currency bonds, unabated by the global financial crisis and accelerating in the post-crisis period. Part of the increase in EME allocations is associated with global "push" factors such as low US long-term interest rates and unconventional monetary policy as well as subdued risk aversion/expected volatility. But also evident is investor differentiation among EMEs, with the largest reallocations going to those EMEs with strong macroeconomic fundamentals such as less volatile inflation and more positive current account balances.
\end{abstract}

This paper, revised after the $60^{\text {th }}$ Panel Meeting of Economic Policy (October 2014), was lightly circulated as "International Investors in Local Bond Markets: Indiscriminate Flows or Discriminating Tastes?" The authors thank Sumit Malhotra for excellent research assistance, Robert DeMason of JPMorgan for returns indices, Randolph Tantzscher of Markit for GEMLOC investabilty data, and Branimir Gruic of BIS for data on the size of local currency and USD-denominated bond markets. We also thank for helpful comments the editor (Nicola Fuchs-Schündeln), three anonymous referees, Anusha Chari, Branimir Gruic, Philip Lane, Louis Miserendino, Tommaso Monacelli, Alex Michaelides, and participants at the $60^{\text {th }}$ Panel Meeting of Economic Policy, INFINITI, Australian Conference of Economists, Banco Central de Reserva del Perú and NIPFP. Burger acknowledges a research sabbatical from Loyola University Maryland. 
"The extent to which distortions in one country may spread to financial market developments in the other EMEs will depend to a great degree also on whether international investors look at the EMEs as a homogeneous asset class or whether they take an increasingly differentiated view in their evaluations of individual EMEs and their respective progress towards achieving macroeconomic stability. The varying reactions of bond markets in some EMEs following a rise in volatility over the last two years indicate that international investors are beginning to make a greater distinction between those countries' bond markets depending on how the fundamentals are assessed; yet it remains to be seen whether, and to what extent, this development is a lasting one."

Bundesbank, Financial Stability Review 2007

“...our greatest concern is financial market fragmentation..." Mario Draghi, August 2, 2012

\section{Introduction}

Investor behavior in bond markets is of great interest to policymakers in both emerging market economies (EMEs) and advanced economies (AEs). For EME bond markets, the Bundesbank opines that financial stability would improve if global investors differentiated between them. In Eurozone bond markets, the ECB equates differentiation with a fragmentation that could impede the monetary policy transmission mechanism, suggesting that differentiation is not always and everywhere desirable. In the background is an environment for investing in international bonds that has changed dramatically over the past few decades with the development of EME local currency bond markets (LCBMs). EMEs with low inflation, stronger institutions, and well defined creditor rights have experienced substantial development of LCBMs (see Burger and Warnock 2003, 2006; Eichengreen and Luengnaruemitchai 2006, Claessens, Klingebiel, and Schmukler 2007). The ability to borrow in the local currency is a positive development that enhances financial stability by ameliorating the currency mismatches that were at the center of past crises (Goldstein and Turner 2004). However, large inflows of foreign investment can be problematic, as most extreme capital flow episodes (surges and stops, for example) are driven by debt flows (Forbes and Warnock 2013), credit booms lead to crises (Mendoza and 
Terrones 2008, Gourinchas and Obstfeld 2012, Schularick and Taylor 2012), and large foreign

investment flows into LCBMs can complicate the tasks of EME policymakers by appreciating real exchange rates, fanning asset price bubbles, and intensifying lending booms. Indeed, the threat of the virtuous cycle turning vicious when unconventional monetary policy (UMP) by many AE central banks may have propelled a global search for yield has many EME policymakers worrying about exactly those problems: excessive upward pressure on the local currency, indiscriminate flows into EMEs creating bond market bubbles that enable increasingly risky borrowing, and the potential for an external shock (such as Federal Reserve going from "tapering" to outright tightening) prompting a stampede for the exits.

But how do international bond investors actually behave? The literature suggests many possibilities. In the midst of the recent global financial crisis, the pattern of capital flows was highly heterogeneous across types of flows and destinations (Milesi-Ferretti and Tille 2012) and international investors, with their pro-cyclical behavior of reducing international exposure during bad times and increasing exposure when conditions improved, were destabilizing to markets and exposed countries to foreign shocks (Raddatz and Schmukler 2012). Another view is that while common shocks - key crisis events as well as changes in global liquidity and risk - exerted a large effect on capital flows both during the crisis and in the recovery, the effects were highly heterogeneous across countries, with this heterogeneity being largely explained by differences in the quality of domestic institutions, country risk and the strength of domestic macroeconomic fundamentals (Fratzscher 2012).

In this paper we view global bond markets from the perspective of a U.S. investor and attempt to understand what drives foreigners' reallocations towards and away from certain bond markets. We focus primarily but not exclusively on LCBMs, which is warranted because they comprise over 90 
percent of the global bond market and have far-reaching implications. ${ }^{1}$ For example, the original meaning of the US exorbitant privilege came from the ability of the US to borrow internationally through its local currency bonds; that is, even back in the 1960 s foreigners tended to purchase US Treasury bonds (that is, US local currency sovereign bonds). Also, the original sin hypothesis of Eichengreen and Hausmann (1999) focused on EMEs' inability to borrow internationally in their own currency; if EMEs can now attract foreign investors to their LCBMs, the Eichengreen and Hausmann (1999) original sin would be alleviated. That said, while we have a natural inclination to study local currency bonds, foreign currency debt is also important-the currency mismatches that generated crises in 1980s Latin American, 1990s Asia, and more recently Iceland are one manifestation of excessive reliance on foreign currency debt-so we also analyze USD-denominated bonds.

We begin by describing some salient features of global bond markets. The structure of EME bond markets has improved dramatically over the past decade. Many EMEs have lessened their reliance on foreign currency bonds; for example, by 2011 even Latin America, the poster child for original sin, had three-quarters of all its outstanding bonds denominated in the local currency. On average, most EME bonds are now denominated in the local currency and tend to be sovereign bonds, although local currency denominated bonds issued by the private sector has increased sharply since 2007. By 2011 USD-denominated EME bonds-once the dominant EME asset class for many global investors-represented less than $10 \%$ of total EME bonds outstanding. ${ }^{2}$

\footnotetext{
${ }^{1}$ For this study, a local currency bond is denominated in the currency of the country that the issuer resides, in keeping with residency-based international accounts. A recent focus on the ultimate nationality of the issuer-for example, when a Chinese firm issues a yuan-denominated bond through an off-shore subsidiary (see, for example, McCauley et al 2013) - is relevant but beyond the scope of our study.

${ }^{2}$ In AEs, bonds are mostly local currency denominated, with the amount of private-sector and government bonds being roughly equal. USD-denominated AE bonds are quite small, issued primarily by the private sector.
} 
The description of LCBMs' size and structure is informative, but our main goal is to examine the portfolio reallocations of US investors from 2006 to 2011, a period that spans bubble years, the global financial crisis, and currency wars. We employ country-level holdings data built from high-quality security-level data collected by the US Treasury, data that include information about the bonds' currency denomination. This dataset allows us to analyze, among other things, the impact of US monetary policy on US investor positions in local currency bonds, a point central to currency war claims. We are aware of no study of active portfolio reallocations within international investors' local currency bond portfolios; we aim to fill this gap.

The holdings data show, strikingly, that even during the crisis US investors increased their relative portfolio weight (that is, the portfolio weight relative to a global benchmark) on EME LCBMs. EME local currency bonds were $4.9 \%$ of the global local currency bond market in 2001 and grew to $7.8 \%$ in 2011, so some increase in US holdings might be expected. But US holdings increased even faster, with EME bonds increasing to $17.2 \%$ of US investors' cross-border local currency bond portfolio by 2011 from only $1.1 \%$ in 2001. Indeed, for local currency bonds the relative weight for EMEs now exceeds that for AEs. US investors' portfolios of EME local currency bonds are closer to benchmark (international CAPM) weights than are their holdings of AE local currency bonds.

Our empirical assessment of the international bond portfolios shows that global factors (especially the level of US long-term rates) were associated with reallocations toward EME local currency bonds. However, US investors also differentiated among bond markets based on countrylevel macroeconomic factors such as inflation volatility and current account balances. For USDdenominated bonds, the factors associated with active reallocations are quite different, with local factors far more important than global factors. Splitting the bonds by sector of issuer (private or 
government), we find that much of our results pertain to government bonds; our models explain less of the year-by-year variation in active reallocations within US investors' portfolios of private-sector foreign bonds.

Our paper is related to a number of literatures. It adds to the literature on global and local factors. Calvo et al. (1993) noted the importance of global factors such as US interest rates in explaining capital inflows. Chuhan et al. (1998) made the important contribution of separating different types of flows and found that global factors were important in explaining capital inflows, but that country-specific developments were at least as important. Many subsequent papers confirmed the main points of Calvo et al. (1993) and Chuhan et al. (1998), a recent one being Fratzscher (2012) which, using weekly fund flow data, finds that global factors were the main drivers of capital flows in the midst of the recent crisis, but that country-specific determinants were dominant in the years immediately following the crisis. All of these papers use flow data, which as Ahmed et al. (2015) note include a 'portfolio growth' component that is quite directly related to global conditions (such as investor-country financial wealth). Our paper instead focuses on active portfolio reallocations and finds an almost equal role for global and local factors. Our paper is also directly related to past work on international investment in bonds that includes, among others, Lane (2006) and Fidora et al. (2007) and on US investors' local currency bond portfolios (Burger and Warnock 2007; Burger, Warnock, and Warnock 2012). ${ }^{3}$ A closely related but separate literature is on cross-border banking flows; see, for example, and Blank and Buch (2007) and Hale and Obstfeld (2014).

Our assessment of international investment in bonds begins in the next section with a discussion of a framework for assessing portfolio reallocations. In Section 3 we describe the evolution

\footnotetext{
${ }^{3}$ Data availability limited past studies of US investors' foreign bond portfolios to cross-sectional snapshots at a particular point in time. Available time series now enable a study of portfolio reallocations in local currency bond markets over time.
} 
of global bond markets. In Section 4 we discuss US investors' global bond portfolios and analyze factors, including the Fed's UMP, behind active reallocations within US investors' bond portfolios during the 2006-11 period, a time that spans the global financial crisis. Section 5 concludes.

\section{Requirements for Analyzing Portfolio Reallocations: Measure and Data}

Our main objective is to analyze active portfolio reallocations within global bond markets.

Forming a suitable measure of active reallocations is not straightforward; for details on this, see Box 1.

Our preferred measure of active portfolio reallocations is relative weight. Country $i$ 's relative portfolio weight in US portfolios is the ratio of its weight in US investors' portfolio to its weight in the global market. Relative weight, which is asset-class specific, is defined for local currency bonds as:

$$
\operatorname{Re} l W g t_{i}^{U S}=\frac{\omega_{i, U S}}{\omega_{i, m}}=\frac{{ }_{l c} H_{i}^{U S} / \sum_{i}{ }_{l c} H_{i}^{U S}}{{ }^{U S} C a p_{i} / \sum_{i}{ }_{l c} M C a p_{i}}
$$

where $\left[{ }_{l c} \dot{H}_{i}^{U S}\right]$ is defined as US investors' holdings of country $i^{\prime}$ s local currency bonds and $\sum_{i}{ }_{l c} H_{i}^{U S}$. represents the global portfolio of local currency bonds held by US investors, while $\left[{ }_{l c} M C_{i} a p_{i}\right.$ is the market capitalization of country $i$ 's local currency bond market and $\left[\sum_{i}{ }_{i c} \dot{M C a p}{ }_{i}\right.$ is the market capitalization of the global local currency bond market.

Relative portfolio weight is motivated by a global CAPM. If the portfolio weight assigned to a particular bond market equals its relative weight in the global bond market, the relative weight for that market is one. In reality, US investors' relative portfolio weights are often far less than one-this is one dimension of the well-known home bias in asset holdings-because over 90 percent of US investors' bond holdings are issued by US entities. That said, when we focus on certain asset classes-such as 
USD-denominated foreign bonds marketed directly to US investors-relative weights can and sometimes do exceed one.

To form the relative weight measure requires data on bond portfolios and the size of bond markets, both disaggregated by the currency denomination of the bond. Few datasets are suitable for research on international bond portfolios; for details on data requirements and available data on holdings and outstandings, see Box 2.

\section{International Bond Portfolios: The Global Benchmark}

Before turning to our primary analysis of portfolio reallocations, we present salient features of the global bond market, focusing specifically on size and structure. Table 1 presents information by region on the size and composition of global bond markets as of 2011. Selected data on each country in our sample is provided in Appendix Table 1 . Some facts are worth noting. At the end of 2011, the size of global bond markets was $\$ 83$ trillion, almost triple the $\$ 30$ trillion in 2001 . For countries in our sample, most bonds-91\% of AE bonds and $88 \%$ of EME bonds-are local currency denominated. Bond markets are much larger in AEs (161\% of GDP) than in EMEs (29\% of GDP) but have grown substantially in both. AE local bond markets have grown from being roughly equal to AE GDP in 2001 to 1.6 times AE GDP in 2011. Over that period EME local bond markets grew from 20 percent to 29 percent of EME GDP. EME local currency bonds have more than doubled as a share of the total global bond market from 3.3\% in 2001 to $7.1 \%$ in 2011. Furthermore, with larger local currency bond markets, EMEs have become much less reliant on foreign currency borrowing. The share of EME bonds denominated in a foreign currency has fallen from $29 \%$ in 2001 to only $12 \%$ in 2011 . The development of local currency bond markets, impressive across of wide set of EMEs, has been particularly striking in Latin America. In 
2001 nearly half of Latin American bonds were denominated in foreign currency, but by 2011 local currency bond markets had grown so much that foreign currency bonds were only one quarter of bonds in the region. ${ }^{4}$

The evolution of bond markets is evident in the graphs in Figure 1. As a share of GDP, local currency bond markets are largest in AEs, whereas EME bond markets are, on average, quite small (Figure 1, top left). That said, the structure of many EME bond markets has improved dramatically over the past decade. Many EMEs have lessened their reliance on foreign currency bonds (Fig. 1, bottom left). EME bond markets seem to have room to grow (that is, they are all small, as Fig. 1 top left shows), and recent growth has been accompanied by a move toward an improved structure (that is, growth in local currency bonds, with less of a dependence on foreign currency denominated debt).

Digging a bit deeper, we next split on the currency denomination of bonds issued by governments vs. those issued by private entities. AE bonds (Fig. 1, top right) are mostly local currency and are split roughly equally between private (blue bars) and government (green bars). In EMEs (Fig. 1, bottom right), most bonds are sovereign and denominated in the local currency (green bars), although local currency denominated bonds issued by the private sector (blue bars) have increased sharply since 2007.

\title{
4. International Bond Portfolios: US Investors
}

\author{
4.1 Descriptive Analysis
}

\footnotetext{
${ }^{4}$ Reduced reliance on foreign currency borrowing alleviated the fear of floating (Calvo and Reinhart 2002) and facilitated new policy regimes with inflation targeting central banks and flexible exchange rates. Improved policies and better developed local bond markets might have enabled EMEs in general, and Latin America in particular, to weather the global financial crisis much better than the Asian financial crisis of the late 1990s (Alvarez and De Gregorio 2013, Vegh and Vuletin 2013).
} 
Table 2 provides a snapshot of US portfolios at end-2011. Evolution through time is provided in Figures 2 and 3. The local currency bond portfolio of US investors has grown from \$152 billion in 2001 to almost $\$ 500$ billion in 2011 (Figure 2, top panel). The foreign-issued USD-denominated portfolio is substantially larger at almost $\$ 1500$ billion; most of the USD-denominated foreign bonds were issued by private sector entities in Caribbean Financial Centers and just a handful of other countries such as Australia, Canada, the Netherlands, and Sweden (Bertaut, Tabova, and Wong 2013).

Overall, local currency bonds have been a relatively stable 25-30 percent of US investors' foreign bond portfolio. But for EMEs the story is quite different. The share of local currency bonds in US investors' EME bond portfolios ballooned to almost 40\% in 2011 from only 2\% in 2001 (Figure 2, bottom panel). Gone are the days when US investors shunned local-currency denominated EME bonds. While most US holdings of local currency bonds are in AEs (Fig. 3.1, top left), US holdings of EME LCBs have increased substantially over the past decade (Fig. 3.1, bottom left). With both the amount invested and the size of the markets increasing, it is an open question whether US investors have become less underweight in these markets. Interestingly, not only have US investors have become less underweight in many EME LCBMs, they are less underweight in EMEs than in AEs (Figure 3.1, top right). The variation we attempt to understand is within-country changes in US relative weights. For example, Fig. 3.1 (bottom right) shows variation in US relative weights for one set of countries - LatAm EMEs - for local currency bonds. In our empirical analysis we aim to understand why, for example, US investors became less underweight (i.e. relative weight increased) on Mexico in 2011.

Digging further into the splits of US holdings by issuer type and currency denomination reveals some interesting facts. The vast majority of US holdings of AE bonds are USD-denominated bonds 
issued by private entities (Fig. 3.2, top left, maroon bars). US holdings of AE government bonds are primarily denominated in local currency (green bars). US investors' EME holdings (Fig. 3.2, bottom left) are more diverse. The only segment avoided is private-sector issued local currency bonds (a sector that has grown substantially the past few years). Holdings of sovereign local currency bonds (green) has increased the most since 2007 and is now the largest component, but holdings of sovereign USDdenominated bonds (orange) are also quite large. Also sizeable are holdings of EME private-sector USD-denominated bonds-a potential area of concern due to possible currency mismatches. Note that relative weights for USD bonds (Fig. 3.2, top and bottom right; Table 2, rightmost columns) tend to be much higher than for local currency bonds. ${ }^{5}$

In summary, the weight of EME local currency bonds in US investors' bond portfolios has increased relative to the share of EME local currency bonds in the global bond market. EME local currency bonds were $4.9 \%$ of the global local currency bond market in 2001 and grew to $7.8 \%$ in 2011. US holdings increased even faster, increasing from $1.1 \%$ of the cross-border local currency bond portfolio in 2001 to $17.2 \%$ by 2011. The relative weight measure for EME local currency bonds in US investors' portfolios, after a dramatic increase over the past decade, now exceeds the relative weight of AE local currency markets. In other words, in US investors' portfolios of EME local currency bonds are closer to benchmark (ICAPM) weights than are AE local currency bonds.

\subsection{Empirical Analysis of US Investors' Foreign Bond Portfolios}

\footnotetext{
${ }^{5}$ This fact — that relative weights are higher for bonds issued in the investors' currency—likely holds for other investor countries and means that datasets like the IMF's CPIS that do not differentiate by currency denomination mix very different assets.
} 
Over the past decade, US investors have increased their cross-border holdings of local currency bonds, especially in EMEs. We use a common framework to analyze the evolution US investors' country-specific relative portfolio weights-that is, their portfolio weights relative to a global benchmark (as described in Box 1) -in various types of foreign bonds. When portfolio weights differ from benchmark weights, price changes can influence relative weight, so we follow Ahmed et al (2015) and normalize (1) by the home relative weight to isolate active reallocations: ${ }^{6}$

$$
\text { norm } \operatorname{Re} l W g t=\frac{\omega_{i, U S}}{\omega_{i . m}} / \frac{\omega_{U S, U S}}{\omega_{U S . m}} \text {. }
$$

Our annual panel dataset of US investor relative portfolio weights includes 38 destination countries over the 2006-2011 period. ${ }^{7}$ For explanatory variables, we include country-specific "pull" factors such as yield (to proxy for expected return), macroeconomic indicators (GDP growth rate, volatility of inflation, and current account balance), institutional variables, and a proxy for the openness of a country's bond market to foreign investment. For global "push" factors we include the volatility index VIX (which measures variation in expected volatility and risk appetite), the 10-year US Treasury rate (to capture a "reach for yield"), and a measure of unconventional monetary policy (or UMP, defined as changes in the size of Federal Reserve securities holdings scaled by nominal GDP). The macroeconomic indicators included in our regressions represent factors that likely impact the attractiveness of an economy as a destination for cross-border bond investment. Inflation volatility

\footnotetext{
${ }^{6}$ The normalization, which is consistent with the Bekaert and Wang (2009) adjustment for the amount of the source country's home bias, does not materially affect any of our regression results.

${ }^{7}$ The number of destination countries is limited not by the holdings data, but by data on the size and composition of bond markets and for explanatory variables.
} 
(calculated as a rolling, trailing 12-quarter standard deviation) is included as a proxy for the uncertainty of ex ante real returns; increased inflation volatility will also lead to more volatile nominal bond yields thus increasing reinvestment risk. We include the current account to real GDP ratio to proxy for financial imbalances. A country that runs a current account deficit must attract inflows; if those inflows do not materialize, adverse financial market outcomes (such as currency depreciation and/or a spike in bond rates) are likely. We also include the 3-year average growth rate in real GDP per capita as an indicator of the vigor of the destination economy. ${ }^{8}$ Our primary institutional variable is a measure of regulatory quality and creditor rights, calculated as a weighted average of the Regulatory Quality Index from the World Bank's World Governance Indicators and the Legal Rights Index from the "Getting Credit" section of the World Bank's Doing Business report. ${ }^{9}$ Our measure of the openness of a country's local currency bond market to foreign investment is de jure and based on two sources. For 38 EMEs, Markit (2013) has constructed detailed measures for 2010 and 2011 based on the IMF's AREAER documents. We create 2006-11 measures by combining information from Markit's 2010 and 2011 measures with AREAER information for the entire period. The resulting measure is 0 if a country's local currency bond market is by law completely closed to foreign investors and 100 if there are no impediments to foreign investment. ${ }^{10}$

\subsubsection{Panel Results for Local Currency Portfolio Reallocations}

Table 3 presents panel regression results for LCBs. The dependent variable is the normalized relative portfolio weight for local currency bonds as defined in equation (2), and in each regression we

\footnotetext{
${ }^{8}$ At a reviewer's request, we re-estimated regressions with two other potential explanatory variables: the level of inflation (which is likely captured by our yield variable) and volatility of real GDP. Neither offered significant explanatory power. ${ }^{9}$ The regulatory quality index measures a government's ability to formulate and implement sound policies and regulations that promote private sector development, while the creditor rights index measures the degree to which collateral and bankruptcy laws protect the rights of borrowers and lenders. We follow the GEMLOC Investability Indicator Methodology (Markit 2013) by constructing a composite measure with twice the weight on regulatory quality. An equal-weighted measure yields similar results.

${ }^{10}$ In constructing our financial openness measure we assume there are no impediments to investment in AE bond markets.
} 
include fixed destination-country effects and cluster standard errors by country. In addition to the country fixed effects we also include either time fixed effects or specific global "push" factors. The time effects capture the impact of global forces on relative local currency bond allocations during each year in the sample; coefficients for 2007-2011 are reported and should be interpreted relative to 2006.

Results from the two-way fixed-effects specification for the full sample as well as the AE and EME subsamples are reported in the first three columns of Table 3. For the AE subsample (col. 2) we find that US investors reallocated toward local currency bond markets in economies with stronger economic growth. The role of economic growth is economically significant as the estimated coefficients reported in column (2) of Table 3 suggest that the relatively severe 2008-09 recession in Denmark can explain the significant coincident reallocation by US investors away from Danish Krone denominated bonds. At the same time, US investors increased their allocations toward Australian Dollar and South Korean Won denominated bonds. Our model suggests this is due in part to the relatively mild 2009 recessions experienced in these destination economies.

Our model has greater explanatory power for the EME subsample (col. 3). Strikingly, the coefficients on the time dummies suggest a steady increase in allocations toward local currency EME bonds over the time period, even during the height of the global financial crisis. Local factors also mattered. US investors reallocated toward local currency bond markets of EMEs with higher bond yields, more positive current account balances and more stable inflation. The most statistically and economically significant local factor is inflation volatility. For example, the coefficients in column (3) suggest that the stabilization of South African inflation over our sample period explains roughly $25 \%$ of US investors' reallocation into rand-denominated bonds. 
The advantage of the two-way fixed-effects specification is that it shows the impact of global forces on bond allocations over time without having to specify the precise nature of the global variables. The disadvantage is that all the global factors are summarized in the time dummies, which does not allow specific interpretation of, for example, the roles of US monetary policy and global risk aversion. Given the difficulty in properly capturing these specific global factors, one could argue that the two-way fixed effects is the sounder econometric approach, but for completeness in columns (4)(6) we include global "push" factors and omit the time fixed effects.

When including global "push" factors, we find important roles for both global and countryspecific factors. When US Treasury rates fall, US investors increase positions in AE and EME local currency bond markets. In column (6), the positive coefficient on the Federal Reserve's Large Scale Asset Purchases (LSAP) suggests a statistically significant "push" effect of UMP toward EME LC bond markets that is beyond the conventional channel of US Treasury rates. In addition, US investors decrease their cross-border exposure to AE and EME local currency bonds during periods of increased volatility (and/or risk aversion). Local factors also matter in these specifications. We again find that US investors reallocated toward AE local currency bond markets in economies with stronger economic growth and away from EME bond markets within volatile inflationary environments. The coefficients on the country-level institutional variables are statistically insignificant, but given the limited time variation in these variables much of their explanatory power is likely absorbed by the country-level fixed effects.

In general, the results in Table 3 are consistent with the notion that UMP and low U.S. Treasury yields pushed US investors into EME bonds over the period from 2006 to 2011. But local factors mattered too. To gauge the relative importance of global and local factors we follow Bekaert and Wang 
(2009) and conduct a variance decomposition (VARC) analysis. The relative explanatory power of regressor $x$ is computed as:

$$
V A R C_{x}=\hat{\beta}_{x} \frac{\operatorname{cov}(\hat{y}, x)}{\operatorname{var}(\hat{y})}
$$

By construction the VARCs of all the regressors sum to one, therefore the VARC for a particular explanatory variable represents its relative contribution. For the EME model in column (3), we find that $35 \%$ of the variation is determined by our local explanatory variables while $65 \%$ of the variation is explained by global factors. ${ }^{11}$ Of the local variables inflation volatility has the highest VARC at $20 \%$. Repeating the exercise for column (6) produces a 40/60 split between local and global factors, with the US 10-yr Treasury rate dominating with a VARC of 58\%. That is, the classic result of low US rates being associated with a surge in EME investment holds when we focus on EME local currency bonds, providing a plausible channel through which US monetary policy could have contributed to the appreciation of EME currencies (and also providing support to currency war claims).

\subsubsection{Panel Results on USD-denominated Portfolio Reallocations}

While our primary focus is on local currency bonds, in Table 4 we analyze portfolio reallocations in USD-denominated bonds. The dependent variable for our empirical analysis of USD-denominated bonds is normalized relative weight, where relative weight is defined as:

$\frac{\omega_{i, U S}}{\omega_{i . m}}=\frac{{ }_{u s d} H_{i}^{\dot{U S}} / \sum_{i}{ }_{u s d} H_{i}^{U S}}{\operatorname{MCap}_{i} / \sum_{i}{ }_{u s d} M C a p_{i}}$.

where $\left.{ }_{\text {usd }} H_{i}^{U S}\right]$ is US investors' holdings of country i's USD-denominated bonds and $\sum_{i}{ }_{u s d} H_{i}^{U S}$. represents the global portfolio of USD-denominated bonds held by US investors, while $\left[{ }_{{ }_{u s d} M \operatorname{Cap}_{i}}\right.$ is the

\footnotetext{
${ }^{11}$ Note that we are decomposing the variance net of the country fixed effects.
} 
market capitalization of country i's USD-denominated bond market and $\sum_{i}$ usd $_{\text {MCap }}$, is the market capitalization of the global USD-denominated bond market. We again include fixed destination-country effects, either time fixed effects or global "push" factors, and country-level "pull" factors.

In contrast to the results for local currency bonds, the time fixed effects for USD-denominated bonds are almost always insignificant (Table 4). Reallocation toward USD-denominated EME bonds is associated with lower US rates and lower VIX (col. 6).

While the effects of global factors on USD-denominated are muted, we do find a significant impact of local factors on US investment in USD-denominated EME bonds. The results in columns (3) and (6) indicate that more positive current account balances and lower inflation volatility were associated with rising relative US allocations. To gauge the relative importance of global and local factors we again conduct a variance decomposition analysis, this time for the USD-denominated allocations of columns (3) and (6). For the time effects specification we find that $78 \%$ of the variance is explained by local factors, with the most important variables being current account (62\%) and inflation volatility (14\%). Repeating the exercise with specific global factors reveals a similar local-global splitlocal factors matter most for reallocations within the USD-denominated EME bond portfolio-with the most important global factor being VIX (17\%).

\subsubsection{Sectoral Results}

Tables 5 and 6 show results split by the sector (private or government) that issued the bond. ${ }^{12}$ For local currency (Table 5) or USD-denominated bonds (Table 6), the sectoral results show that our main regressions are most able to explain portfolio reallocations within government bond portfolios.

\footnotetext{
${ }^{12}$ Sectoral splits for US holdings are available beginning in 2007 , therefore reducing the sample size relative to the results reported in Tables 4 and 5 .
} 
Results for the government bonds columns in Tables 5 and 6 are quite similar to those in Tables 3 and

4. The time effects in columns (2) and (3) of Table 5 indicate a reallocation away from AE sovereign bond markets and into EME sovereign bonds throughout the sample period. For samples restricted to private-sector bonds, there is very limited explanatory power and very few significant coefficients.

\section{Conclusion}

In 2007 when market volatility was on the rise (but nowhere near its peak), the Bundesbank pondered (see opening quote) the role emerging LCBMs would play in promoting (or inhibiting) global financial stability. While the ensuing global financial crisis provided a severe test for these newly developed markets, EMEs avoided another round of currency crises and US investors did not blindly flee the newly developed asset class. Our data indicate that, on average, US investors increased their EME local currency bond allocations during the crisis and this reallocation toward local currency EME bonds accelerated in the post-crisis period. Moreover, our evidence suggests that US investors do not treat EME local currency bonds as a homogenous asset class, but rather discriminate among EMEs based on macroeconomic fundamentals such as inflation volatility and current account balances.

Overall, our results have interesting implications for financial stability and help distinguish between the possibilities of virtuous and vicious cycles in local currency bond markets. The importance of global monetary conditions and risk appetite/expected volatility lend credence to the concerns of EME policy makers who worry that volatile flows will influence exchange rates and real activity. Fears of a vicious cycle with indiscriminate herd-like flows into and out of EMEs are quelled somewhat by our finding that US investors' discriminate among EMEs based on macroeconomic fundamentals. Strong 
macroeconomic conditions should help EMEs attract and retain cross-border investment, which would reinforce a more virtuous cycle in local currency bond markets. 


\section{References}

Ahmed, S., S. Curcuru, F. Warnock, and A. Zlate, 2015. The Two Components of International Capital Flows. mimeo.

Alvarez, R. and J. De Gregorio, 2013. "Why did Latin America and Developing Countries Perform Better in the Global Financial Crisis than in the Asian Crisis?" working paper presented to IMF's $14^{\text {th }}$ Annual Research Conference.

Ammer, J., S. Holland, D. Smith, and F. Warnock, 2012. US International Equity Investment. Journal of Accounting Research 50(5): 1109-1139.

Bekaert, G., and X. Wang, 2009, Home bias revisited, unpublished working paper.

Bertaut, C., A. Tabova, and V. Wong, 2013. "The replacement of safe assets in the US financial bond portfolio and implications for the US financial bond home bias," Working Paper, Federal Reserve Board.

Blank, S., and C. Buch, 2007. The Euro and Cross-Border Banking: Evidence from Bilateral Data. Comparative Economic Studies 49: 389-410.

Burger, J., and F. Warnock, 2003. "Diversification, Original Sin, and International Bond Portfolios," International Finance Discussion Paper \#755, Board of Governors of the Federal Reserve System.

Burger, J., and F. Warnock, 2006. "Local Currency Bond Markets," IMF Staff Papers 53: 133-146.

Burger, J., and F. Warnock, 2007. "Foreign Participation in Local-Currency Bond Markets," Review of Financial Economics 16(3): 291-304.

Burger, J., F. Warnock, and V. Warnock, 2012. "Emerging Local Currency Bond Markets," Financial Analysts Journal 68(4):73-93.

Calvo, Guillermo, Leonardo Leiderman, and Carmen Reinhart. (1993). "Capital Inflows and Real Exchange Rate Appreciation in Latin America: The Role of External Factors." IMF Staff Papers 40(1): 108-151.

Calvo, G. and C. Reinhart, 2002. "Fear of Floating," Quarterly Journal of Economics 177: 379-408.

Chuhan, Punam, Stijn Claessens, and Nlandu Mamingi. (1998). "Equity and bond flows to Latin America and Asia: The Role of Global and Country Factors." Journal of Development Economics 55 (2), 439 463.

Claessens, S., D. Klingebiel, and S. Schmukler, 2007. “Government Bonds in Domestic and Foreign Currency: The Role of Institutional and Macroeconomic Factors." Review of International Economics 15(2): 370-413.

Cooper, I., and E. Kaplanis, 1986. Costs to crossborder investment and international equity market equilibrium. in J. Edwards, J. Franks, C. Mayer and S. Schaefer (eds.), Recent Developments in Corporate Finance. Cambridge University Press, Cambridge.

Eichengreen, B., and R. Hausmann, 1999. Exchange rates and financial fragility. Proceedings, Federal Reserve Bank of Kansas City, pages 329-368. 
Eichengreen, B. and P. Luengnaruemitchai, 2006. “Why Doesn't Asia Have Bigger Bond Markets?" In BIS Papers No 30: Asian Bond Markets: Issues and Prospects. Basel, Switzerland: Bank for International Settlements.

Felettigh, A., and P. Monti, 2008. How to interpret the CPIS data on the distribution of foreign portfolio assets in the presence of sizeable cross-border positions in mutual funds. Evidence for Italy and the main euro-area countries. Banca d'Italia Occasional Paper No. 16.

Fidora, M., M. Fratzscher, and C. Thimann, 2007. Home Bias in Global Bond and Equity Markets: The Role of Real Exchange Rate Volatility. Journal of International Money and Finance 26: 631-655.

Fratzscher, M., 2012. "Capital Flows, Push Versus Pull Factors and the Global Financial Crisis," Journal of International Economics 88(2): 341-356.

Forbes, K., and F. Warnock, 2013. "Debt- and Equity-Led Capital Flow Episodes," in Capital Mobility and Monetary Policy edited by Miguel Fuentes and Carmen M. Reinhart. Santiago: Central Bank of Chile. Also available as NBER Working Paper No. 18329.

Goldstein, M., and P. Turner, 2004. Controlling Currency Mismatches in Emerging Economies. Washington, DC: Institute for International Economics.

Gourinchas, P.-O., and M. Obstfeld, 2012. "Stories of the Twentieth Century for the Twenty-First," American Economic Journal: Macroeconomics 4(1): 226-65.

Griever, W., G. Lee, and F. Warnock, 2001. The U.S. system for measuring cross-border investment in securities: a primer with a discussion of recent developments. Federal Reserve Bulletin 87(10): 633650.

Gruić, B., and P. Wooldridge, 2012. Enhancements to the BIS debt securities statistics. BIS Quarterly Review (December, pages 63-76).

Hale, G., and M. Obstfeld, 2014. The Euro and the Geography of International Debt Flows. mimeo.

Holland, S., S. Sarkissian, M. Schill, and F. Warnock, 2015. Global cross-border equity holdings. Mimeo.

J.P. Morgan, 2002. JPMorgan Government Bond Indices. J.P. Morgan Portfolio Research, January 14.

J.P. Morgan, 2006. Introducing the JPMorgan Government Bond Index-Emerging Markets (GBI-EM): Index Methodology. J.P. Morgan Emerging Markets Research and Bond Index Research, January.

Lane, P., 2006. Global Bond Portfolios and EMU. International Journal of Central Banking 2(2): 1-23.

Markit Indices Limited, 2013. "GEMLOC Investability Indicator Methodlogy," February 2013, https://www.markit.com/assets/en/docs/products/data/indices/bondindices/GEMLOC\%20Investability\%20Indicator\%20Methodology.pdf

McCauley, R., C. Upper, and A. Villar, 2013. Emerging market debt securities issuance in offshore centers. BIS Quarterly Review (September, Box 2).

Mendoza, E. and M. Terrones, 2008. "An Anatomy of Credit Booms: Evidence from Macro Aggregates And Micro Data," NBER Working Paper No. 14049.

Milesi-Ferretti, G.M., and C. Tille, 2012. The great retrenchment: international capital flows during the global financial crisis. Economic Policy 26(66): 289-346. 
Raddatz, C., S.Schmukler, 2012. "On the international transmission of shocks: Micro-evidence from mutual fund portfolios," Journal of International Economics 88(2): 357-374.

Schularick, M., and A. M. Taylor, 2012. "Credit Booms Gone Bust: Monetary Policy, Leverage Cycles, and Financial Crises, 1870-2008." American Economic Review 102: 1029-61.

Tille, Cedric, and Eric van Wincoop, 2010. International Capital Flows. Journal of International Economics 80(2): 157-175.

U.S. Department of the Treasury, Federal Reserve Bank of New York, and Board of Governors of the Federal Reserve System, 2002. Report on Foreign Portfolio Investment in the United States as of December 31, 2001.

2007. Report on Foreign Portfolio Investment in the United States as of December 31, 2006. 2009. Report on Foreign Portfolio Investment in the United States as of December 31, 2008. 2012. Report on Foreign Portfolio Investment in the United States as of December 31, 2011.

Vegh, C. and G. Vuletin, 2013. "The Road to Redeption: Policy Response to Crises in Latin America," working paper presented to IMF's $14^{\text {th }}$ Annual Research Conference. 


\section{Box 1: A Measure of Active Portfolio Reallocations}

Our aim is to assess the factors associated with active portfolio reallocations in global bond markets. The challenge is to create a measure that does not conflate active reallocations with passive reallocations or portfolio growth. Consider the fact that between 2006 and 2011 EME local currency bond markets increased from $4.9 \%$ of the global market to $7.8 \%$. If US investors' holdings had increased passively along with the benchmark weights, they would have doubled from $\$ 19$ to $\$ 38$ billion over that period. But, in addition to the $\$ 19$ billion in passive increases, US investors actively reallocated toward EMEs, adding another $\$ 46$ billion in local currency bond holdings.

To isolate these active portfolio reallocations we follow Ahmed et al. (2015) in using relative weight (equation 1). The relative weight measure, which is simply a country's weight in US investors' portfolio relative to its weight in a benchmark portfolio, is consistent with an international CAPM-based model of international portfolio allocation as presented in Cooper and Kaplanis (1986). That model, described in some detail in Holland et al (2015), includes country-specific proportional investment costs, representing both explicit and implicit costs of investing abroad, and is designed to optimize an investor's allocation of wealth among risky securities in $\mathrm{n}$ countries in order to maximize expected returns net of costs. If there are no costs to investing, the allocation collapses to the global market capitalization allocation; that is, the investor allocates his wealth across countries according to market capitalizations. If costs are non-zero and non-uniform, allocations deviate from market weights. The higher the costs in a particular foreign market, the more severely underweighted that country will be in the investor's portfolios. The international CAPM therefore provides a theoretical underpinning for our focus on relative weight.

An additional complication is that if portfolio weights differ from benchmark weights, then changes in relative prices will cause passive deviations from the benchmark. A simple normalization - dividing relative weight by the relative weight for the home market - isolates active portfolio allocations (Ahmed et al 2015) and is consistent with the Bekaert and Wang (2009) adjustment of scaling by the source country's home bias. In our panel regressions we use normalized relative weights (eq. 2), although we find that this normalization does not materially impact our results. 


\section{Box 2: Features of a Suitable Dataset for Studies of International Bond Portfolios}

A dataset of international bond portfolios must be able to identify the currency denomination of the underlying bonds, not just the location of the issuer. A local currency Thai baht bond, for example, is a very different security from a Thai-issued US dollar-denominated bond. Only a dataset built from security-level data can identify the currency denomination of the underlying bonds.

It is also desirable to use time series data on all foreigners' holdings of each country's local currency bonds. One would need time series data of foreigners' holdings of Malaysian ringit bonds, Indonesian rupiah bonds, euro-denominated bonds issued by German entities, and so on for perhaps 40 or more countries. Unfortunately, such time series data for a large set of countries does not, to our knowledge, exist. Asian Bonds Online covers foreigners' holdings of the government bonds of a handful of Asian countries, but we do not know of a source that includes all foreigners' holdings of the local currency bonds of many countries and is available through time. The IMF Coordinated Portfolio Investment Survey (CPIS) provides data on foreign holdings of many countries' bonds by investor country, but for bond analysis it is severely limited in that it lumps together all bonds without differentiating between local currency- and foreign currency-denominated bonds. Because it does not identify the currency denomination of the bonds, the CPIS dataset might reflect a propensity of one country to issue bonds in the currency of another. Moreover, for countries that do not have well developed mutual fund industries and whose residents thus tend to invest in foreign-domiciled mutual funds, in the CPIS data such investment (even if in bond funds) will be entered as equity investment (because mutual funds are technically equities); see Felettigh and Monti (2008).

In order to analyze foreign holdings through time without making assumptions on foreign holdings, we work with data on the holdings of a particular set of investors: US investors. Focusing on US investors' crossborder bond holdings is limiting in the sense that we can only analyze the portfolios of one group of investors (US investors), but this is quite a large group for which we have high quality, publicly available data. Importantly, US investors' bond holdings are captured by the US Treasury Department at the security level, so the exact nature (including currency denomination) of the bond is known to the data collector. Moreover, no assumptions are necessary. The bond's security ID, when combined with an issuer's dataset, readily provides the country of the issuer as well as the currency denomination of the bond. The security-level holdings data are not currently available to researchers outside the Federal Reserve Board, but the country-level aggregates that are built from the security-level data are available and provide a clean dataset for year-end 2001 and each year-end since 2006. It is these holdings - in particular, the active reallocations within this portfolio - that we will analyze.

Our relative weight measure requires data on the relative size of global bond markets. For data on outstanding bonds by country and currency, placed both domestically and internationally, we rely on unpublished data provided by the Bank of International Settlements (BIS). Because BIS changed methodology in 2012 (see Gruić and Wooldridge 2012) and the newer data might not be consistent with the historical data, our analysis ends in 2011 and our description refers to the pre-2012 methodology.

Traditionally, the BIS data have come in two complementary datasets. One data set is on "domestic debt", which the BIS defines as local currency bonds issued by locals in the local market (i.e., not placed directly abroad). Data are available in BIS Quarterly Review Table 16A (Domestic Debt Securities). Because our study is on bonds, we obtained from BIS the data underlying Table 16A, which allows us to exclude short-term notes and commercial paper and focus on bonds (that is, debt securities with original maturity longer than one year). The other data set is on "international bonds", bonds issued either in a different currency or in a different market. Certain aggregates of this are presented in BIS Quarterly Review Table 14B (International Bonds and Notes by Country of Residence). For our focus we obtained the underlying data from BIS, as we require issuance by currency by country, a split that is not presented in the Quarterly Review.

With these two sources (and our calculations), local-currency-denominated debt is the sum of the longterm debt component of "domestic debt" and the local currency / local issuer portion of "international bonds". The dataset also allows us to separately analyze bonds by sector of the issuer (government or private) and by currency denomination (local currency, as noted, but also foreign currency). 


\section{Data Appendix}

Throughout, "bonds" refer to debt instruments with greater than one year original maturity. We focus on bonds denominated in the currency of the country in which the issuer resides. For details on bond market data, see Box 2.

\section{US Bond Holdings}

Data on US investors' holdings of local currency bonds is from periodic, comprehensive benchmark surveys conducted by the Treasury Department, Board of Governors of the Federal Reserve System, and the Federal Reserve Bank of New York. See the actual surveys, for example, Treasury Department et al. $(2002,2009)$ or the Griever, Lee, and Warnock (2001) primer for details. Briefly, from Griever, Lee, and Warnock (2001), the so-called "asset surveys" of US holdings of foreign securities collect data from two types of reporters: USresident custodians and US institutional investors. Custodians are the primary source of information, typically reporting about 97 percent of total US holdings of foreign long-term securities. Institutional investors, such as mutual funds, pension funds, insurance companies, endowments, and foundations, report in detail on their ownership of foreign securities only if they do not entrust the safekeeping of these securities to US-resident custodians. If they do use US-resident custodians, institutional investors report only the name(s) of the custodian(s) and the amount(s) entrusted (and the data are collected from the custodian, but not double counted). Custodians are asked but not mandated to enter information on the type of investor, so in practice the type of investor (e.g., institutional or retail) is not typically identified; where it has been identified the bulk of holdings $(90+$ percent) are by institutions (mutual funds, pension funds, etc.).

Reporting on the asset surveys is mandatory, with both fines and imprisonment possible for willful failure to report. The data are collected at the security-level, greatly reducing reporting error; armed with a security identifier, a mapping to the currency of the bond and the residence of its issuer is straightforward. Reporting and the data are comprehensive, and the holdings data form the official US data on international positions (for example, the number for international bonds in the Bureau of Economic Analysis's International Investment Position report is formed by aggregating the survey's security-level information).

For our purposes, we needed a split (US holdings of local currency foreign bonds) not usually published in the Treasury Department reports, and so persuaded Treasury to include an 'own currency' column in the published table on holdings by country by currency (see, for example, Table A.6 of Treasury Department et al. 2009). This is our measure of US holdings of local currency bonds. For foreign currency bonds we limit our analysis to USD-denominated bonds; US investors' holdings of third-currency bonds (i.e., not USD and not in the currency of the issuer) are extremely small, amounting to only $2.3 \%$ of their foreign bond portfolio in 2011 .

\section{Explanatory Variables}

As explanatory variables in Tables 3-6, we use various data series. Yield is the yield-to-maturity in the GBI indexes from J.P Morgan and enters our regressions as an annual average. See J.P Morgan (2006) Appendix B. A number of other explanatory variables are from the IMF's IFS database (inflation volatility is computed from three years of quarterly CPI inflation), WEO (current account balance is as a percent of GDP) or WDI (GDP growth, calculated as the 3-year average growth rate in real GDP per capita). VIX and USi10 come from the St. Louis Federal Reserve Database (FRED) and are year-end observations of the CBOE volatility index and 10-year US Constant Maturity Treasury rate, respectively. Federal Reserve holdings of US bonds, used to create our LSAP variable, are from the Fed's H.4.1 release. $r$ egcr is calculated as a weighted average of the Regulatory Quality Index from the World Bank's World Governance Indicators and the Legal Rights Index from the "Getting Credit" section of the World Bank's Doing Business report. The regulatory quality index measures a government's ability to formulate and implement sound policies and regulations that promote private sector development, while the creditor rights index measures the degree to which collateral and bankruptcy laws protect the rights of borrowers and lenders. We follow the GEMLOC Investability Indicator Methodology (Markit 2013) by constructing a composite measure with twice the weight on regulatory quality. An equal weighted measure yields similar results. Finally, caopen is our measure of the openness of a country's local currency bond market to 
foreign investment is de jure and based on two sources. For 38 EMEs, Markit (2013) has constructed detailed measures for 2010 and 2011 based on the IMF's AREAER documents. We create our 2006-11 measures by combining information from Markit's 2010 and 2011 measures with AREAER information for the entire period. The resulting measure is 0 if a country's local currency bond market is by law completely closed to foreign investors and 100 if there are no impediments to foreign investment. In constructing our financial openness measure we assume there are no impediments to investment in AE bond markets.

\section{Country Groupings}

The groupings of "advanced economies", or AEs, and "other emerging market and developing countries" (shortened here to emerging market economies or EMEs) follow IMF classification as of April 2013. See http://www.imf.org/external/pubs/ft/weo/2013/01/pdf/statappx.pdf. 
Figure 1. The Structure of Global Bond Markets
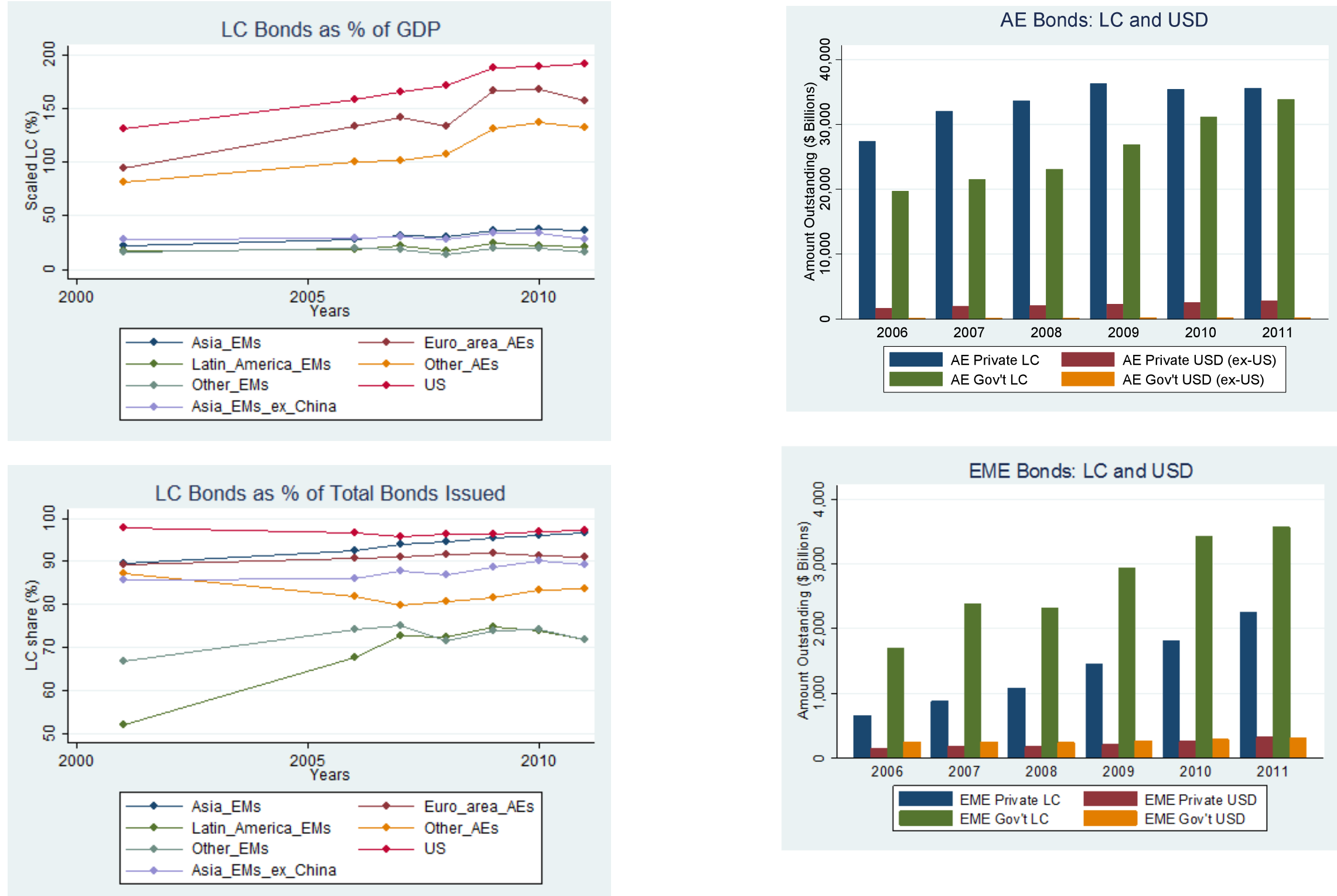
Figure 2. US Investors' Foreign Bond Holdings by Currency, 2001-2011

The top panel shows, for end of year 2001 and 2006-11, the total amount (in billions of USD) of US investors' foreign bond holdings ("Total") as well as the amounts held in USD-denominated ("USD") and local currency ("Local currency") bonds. The bottom panel shows, for US investors' foreign bond holdings as of year ends 2001 and 2006-11, the shares of AE and EME holdings that are denominated in the local currency.
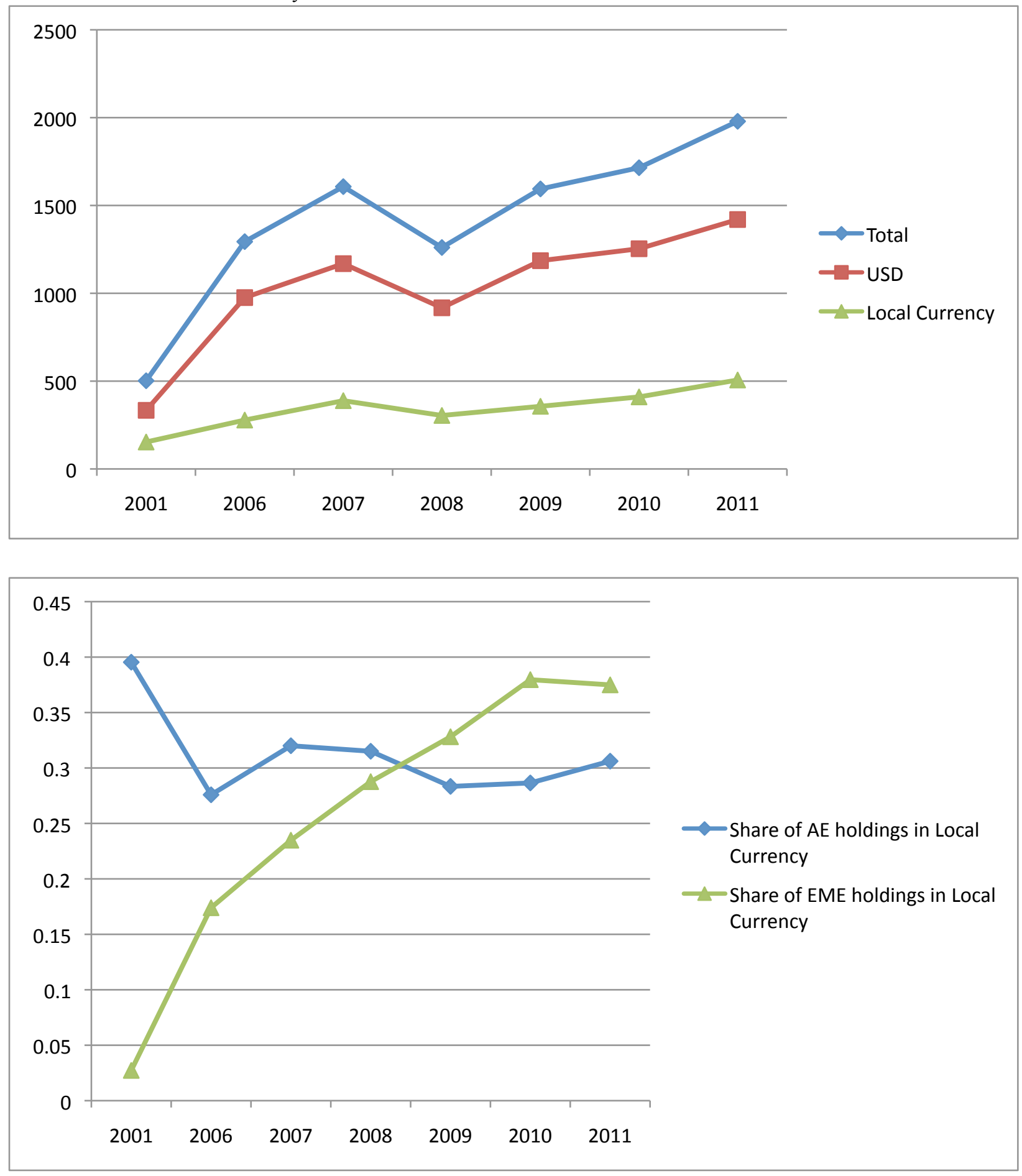


\section{Figure 3.1 US Investors' Bond Portfolios}
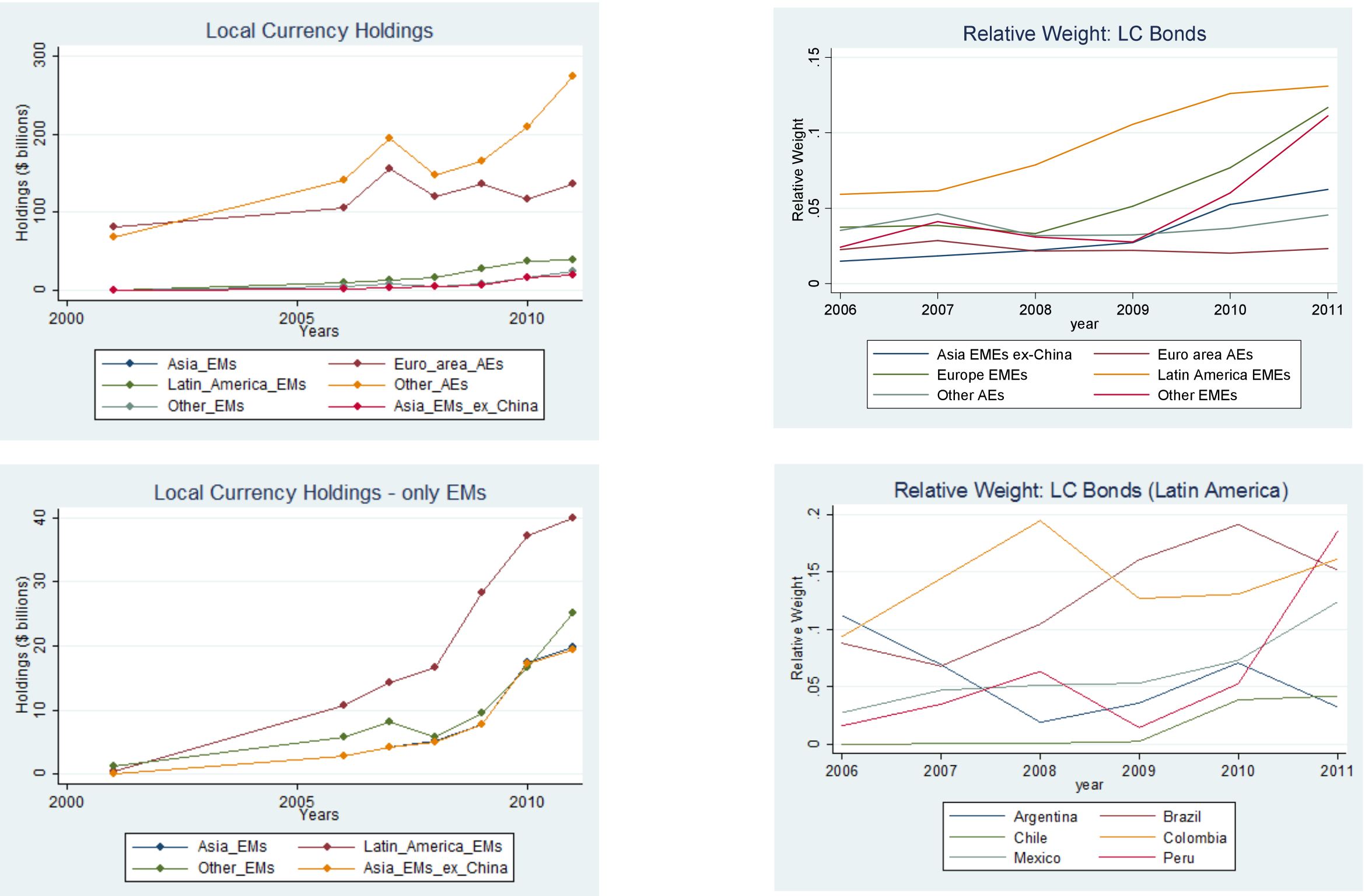
Figure 3.2 US Investors' Bond Portfolios (continued)
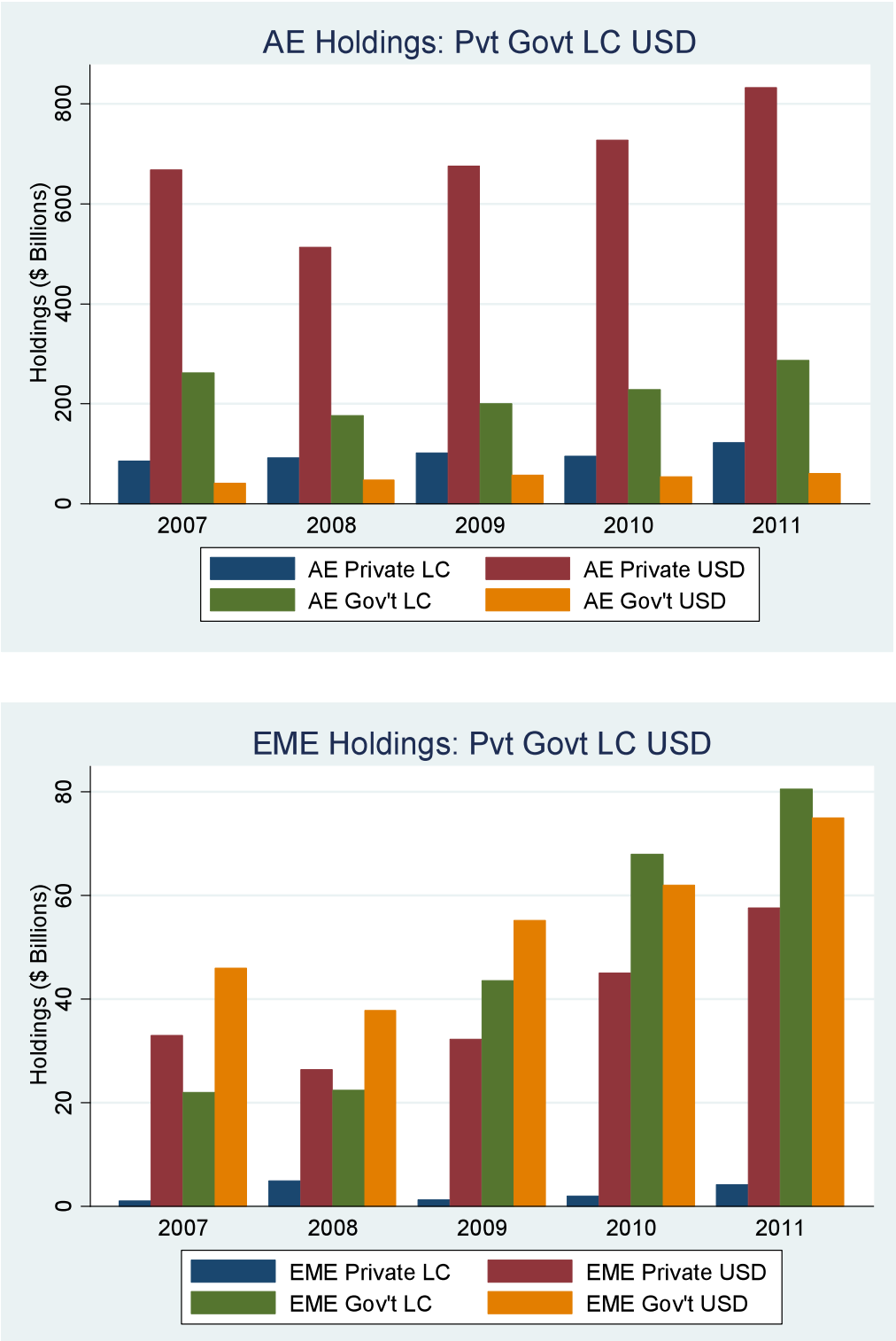
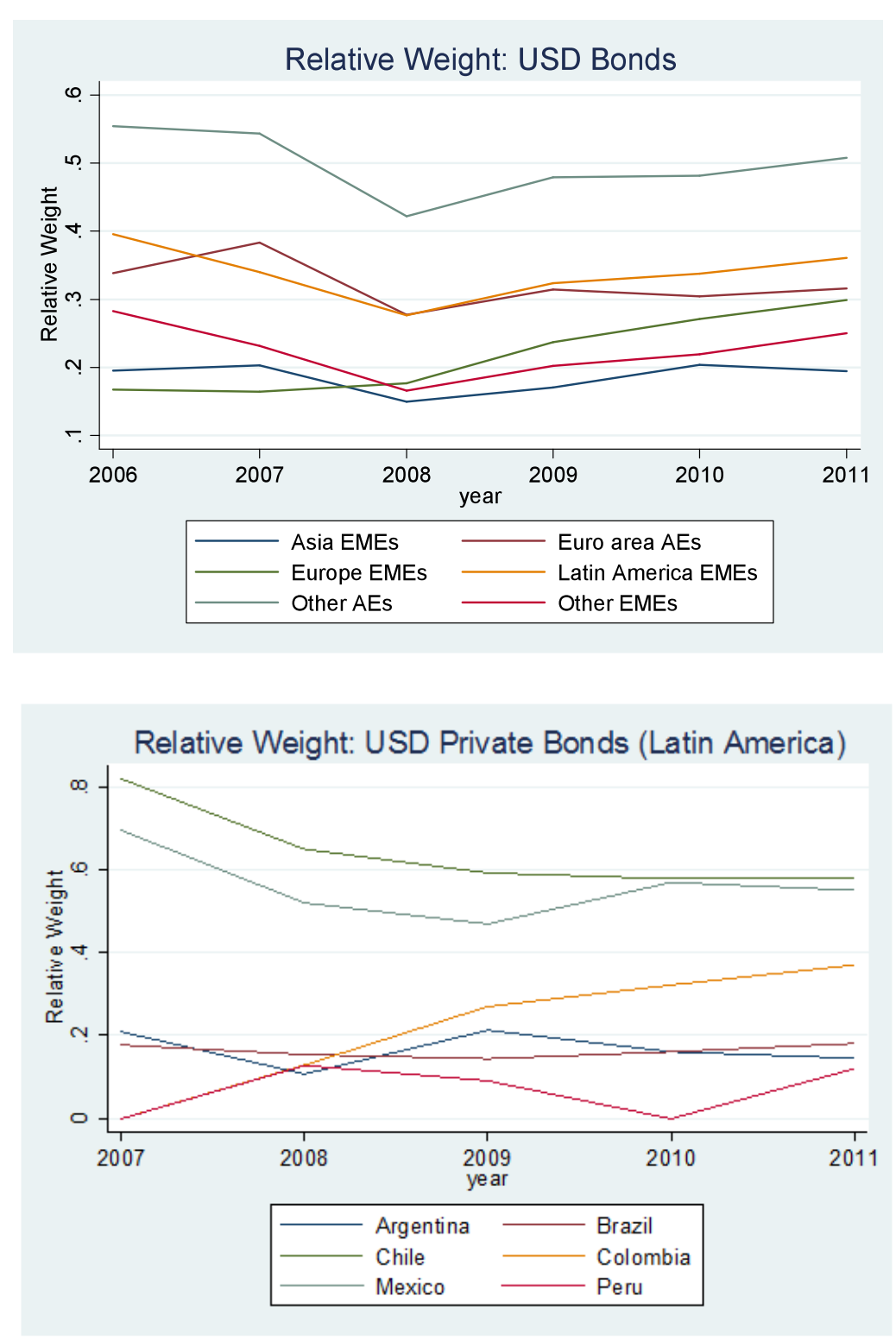
Table 1. Bond Market Characteristics: Summary Statistics by Region

The table shows summary statistics by region as of end-2011. Data on international bonds are built from data that underlie two BIS Quarterly Review tables, Table 14B (International Bonds and Notes by Country of Residence) and Table 16A (Domestic Debt Securities). Local-currency-denominated debt is the sum of the local currency portion of Table 14B and the long-term debt component from Table 16A. The amount of USD-denominated debt is calculated from data underlying Table 14B. Country groupings follow IMF classifications of "advanced economies" and "other emerging market and developing economies" as of April 2013; see http://www.imf.org/external/pubs/ft/weo/2013/01/pdf/statappx.pdf. See Appendix Table 1 for countries included in our dataset.

AEs

Total 75883

Total

Local Currency Denominated

Us\$b

us\$b \%GDP \%total \%govt

US Dollar Denominated

AEs

Euro area $\quad 22106$

$69164 \quad 161$

$20147 \quad 157$

91

49

39

$20387 \quad 134$

US

29409

28630

191

91

71

84

40

US\$̧b \%total

\%govt

EMEs

$\begin{array}{lc}\text { Total } & 6607 \\ \text { Europe } & 699 \\ \text { LatAm } & 1406 \\ \text { Asia } & 4155 \\ \text { Other } & 347\end{array}$

$5818 \quad 29$

$88 \quad 61$

$500 \quad 24$

72

89

$1053 \quad 22$

75

80

$4009 \quad 36$

96

52

$255 \quad 11$

74

75

$\begin{array}{ccc}31598 & 42 & 37 \\ 1071 & 5 & 7 \\ 1896 & 7 & 6 \\ 28630 & 97 & 40\end{array}$

$\begin{array}{ccc}576 & 9 & 49 \\ 68 & 10 & 88 \\ 302 & 21 & 44 \\ 132 & 3 & 38 \\ 75 & 22 & 49\end{array}$




\section{Table 2. US Portfolios: Summary Statistics by Region}

The table shows summary statistics by region of US investors' local currency and USD-denominated bond portfolios as of end-2011. Data are author's calculations using data on US investment from the US Department of the Treasury et al. (2012) and the size of local currency bond markets (mostly from the BIS; see Table 1 for details). Relative weight measures, defined in the text equation (1), are calculated as the the weight of the country in US portfolios relative to its weight in the world market portfolios. A relative weight measure equals one if the weight of the countries' bonds in US and world market portfolios are identical and is less than one if US investors' underweight the country (relative to its market size). See Appendix Table 2 for country-level detail on local currency bond portfolios.

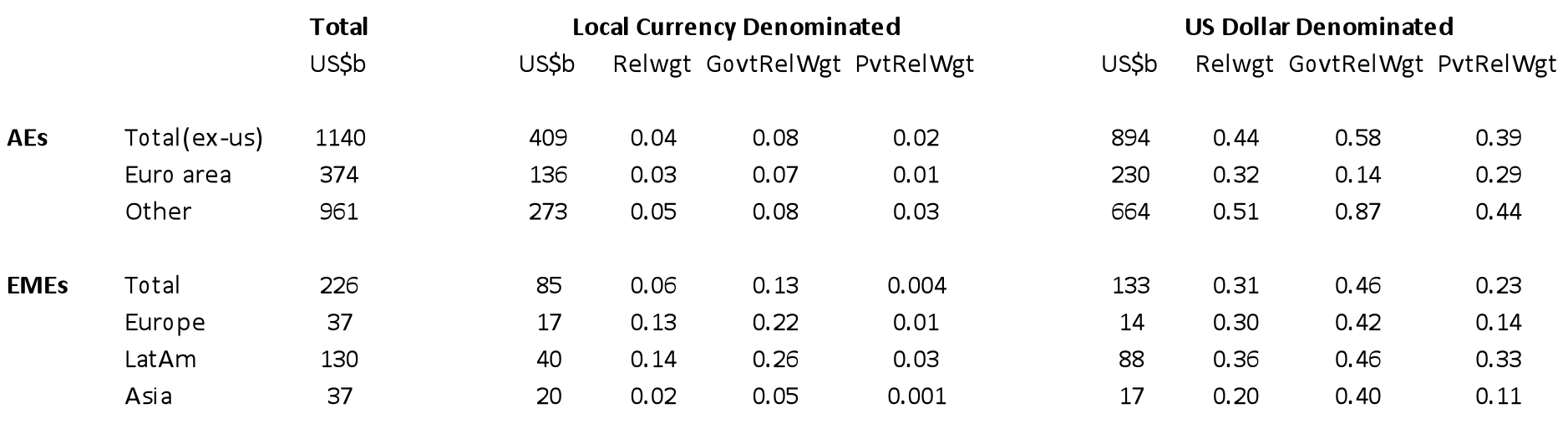


Table 3. Fixed Effects Panel Regression of US Investor Relative Weights, Local Currency Bonds

The table presents panel regressions using annual data from 2006 through 2011. The dependent variable is U.S investors' normalized relative portfolio weight for each country's local currency bonds. The sample includes countries listed in Appendix Table 2 with the exception of Iceland, Norway, Switzerland, Croatia, Argentina, Pakistan, and Philippines, which are excluded based on availability of explanatory variables. Each panel regression includes fixed destination-country effects. Standard errors (reported in parentheses) are clustered at the country level. Output for constants is not shown. $\mathrm{regcr}$ is a measure of regulatory quality and creditor rights. caopen is a measure of openness, with higher scores indicating that a bond market is more open to cross-border investment. $c a \_g d p$ is the current account balance scaled by GDP. Inflation volatility (infvol) is computed on a rolling basis using three years of quarterly data. yield is the annual average of monthly bond yields. growth is calculated as the 3 -year average growth rate in real GDP per capita. ${ }^{*} \mathrm{p}<0.1 ;{ }^{* *} \mathrm{p}<0.05 ; * * * \mathrm{p}<0.01$

\begin{tabular}{|c|c|c|c|c|c|c|}
\hline & $\begin{array}{c}\text { LCTotal All } \\
\text { (1) }\end{array}$ & $\begin{array}{c}\text { LCTotal AE } \\
\text { (2) }\end{array}$ & $\begin{array}{l}\text { LCTotal EME } \\
\text { (3) }\end{array}$ & $\begin{array}{c}\text { LCTotal All } \\
\text { (4) }\end{array}$ & $\begin{array}{l}\text { LCTotal AE } \\
\text { (5) }\end{array}$ & $\begin{array}{c}\text { LCTotal EME } \\
\text { (6) }\end{array}$ \\
\hline regcr & $\begin{array}{l}0.056 \\
(0.043)\end{array}$ & $\begin{array}{l}0.008 \\
(0.056)\end{array}$ & $\begin{array}{l}0.046 \\
(0.040)\end{array}$ & $\begin{array}{l}0.061 \\
(0.043)\end{array}$ & $\begin{array}{r}0.019 \\
(0.052)\end{array}$ & $\begin{array}{r}0.050 \\
(0.045)\end{array}$ \\
\hline caopen & $\begin{array}{r}-0.010 \\
(0.023)\end{array}$ & & $\begin{array}{r}-0.021 \\
(0.018)\end{array}$ & $\begin{array}{r}-0.010 \\
(0.030)\end{array}$ & & $\begin{array}{r}-0.021 \\
(0.026)\end{array}$ \\
\hline ca_gdp & $\begin{array}{r}0.039 \\
(0.056)\end{array}$ & $\begin{array}{r}-0.010 \\
(0.067)\end{array}$ & $\begin{array}{l}0.127 * \\
(0.066)\end{array}$ & $\begin{array}{l}0.044 \\
(0.059)\end{array}$ & $\begin{array}{l}-0.006 \\
(0.073)\end{array}$ & $\begin{array}{r}0.121 \\
(0.076)\end{array}$ \\
\hline infvol & $\begin{array}{l}-0.797 * * * \\
(0.282)\end{array}$ & $\begin{array}{r}0.209 \\
(0.171)\end{array}$ & $\begin{array}{l}-0.803 * * \\
(0.293)\end{array}$ & $\begin{array}{l}-0.695 * * \\
(0.273)\end{array}$ & $\begin{array}{r}0.220 \\
(0.153)\end{array}$ & $\begin{array}{l}-0.651 * * \\
(0.296)\end{array}$ \\
\hline yield & $\begin{array}{l}0.050 \\
(0.055)\end{array}$ & $\begin{array}{r}-0.032 \\
(0.102)\end{array}$ & $\begin{array}{l}0.148^{*} \\
(0.081)\end{array}$ & $\begin{array}{l}0.015 \\
(0.060)\end{array}$ & $\begin{array}{r}-0.027 \\
(0.088)\end{array}$ & $\begin{array}{l}0.090 \\
(0.103)\end{array}$ \\
\hline growth & $\begin{array}{r}0.145 \\
(0.101)\end{array}$ & $\begin{array}{l}0.370 * * \\
(0.177)\end{array}$ & $\begin{array}{r}0.130 \\
(0.116)\end{array}$ & $\begin{array}{r}0.073 \\
(0.088)\end{array}$ & $\begin{array}{l}0.346^{* *} \\
(0.143)\end{array}$ & $\begin{array}{r}0.037 \\
(0.100)\end{array}$ \\
\hline 2007.year & $\begin{array}{r}0.052 \\
(0.179)\end{array}$ & $\begin{array}{r}0.015 \\
(0.205)\end{array}$ & $\begin{array}{r}0.260 \\
(0.365)\end{array}$ & & & \\
\hline 2008.year & $\begin{array}{r}0.439 \\
(0.291)\end{array}$ & $\begin{array}{r}-0.186 \\
(0.194)\end{array}$ & $\begin{array}{l}1.055^{*} \\
(0.513)\end{array}$ & & & \\
\hline 2009.year & $\begin{array}{l}1.242 * * * \\
(0.427)\end{array}$ & $\begin{array}{r}0.534 \\
(0.577)\end{array}$ & $\begin{array}{l}1.628^{* *} \\
(0.638)\end{array}$ & & & \\
\hline 2010.year & $\begin{array}{l}1.861 * * * \\
(0.506)\end{array}$ & $\begin{array}{r}0.813 \\
(0.598)\end{array}$ & $\begin{array}{l}2.986^{* * * *} \\
(0.723)\end{array}$ & & & \\
\hline 2011.year & $\begin{array}{l}2.424 * * * \\
(0.512)\end{array}$ & $\begin{array}{l}1.240^{*} \\
(0.702)\end{array}$ & $\begin{array}{l}3.792 * * * \\
(0.818)\end{array}$ & & & \\
\hline USi10 & & & & $\begin{array}{l}-0.997 * * * \\
(0.206)\end{array}$ & $\begin{array}{l}-0.570 * * \\
(0.255)\end{array}$ & $\begin{array}{l}-1.575^{* * * *} \\
(0.312)\end{array}$ \\
\hline LSAP_gdp & & & & $\begin{array}{l}0.075 * * * \\
(0.023)\end{array}$ & $\begin{array}{r}0.047 \\
(0.036)\end{array}$ & $\begin{array}{l}0.079 * * \\
(0.037)\end{array}$ \\
\hline vix_eoy & & & & $\begin{array}{l}-0.078 * * * \\
(0.016)\end{array}$ & $\begin{array}{c}-0.059 * * * \\
(0.020)\end{array}$ & $\begin{array}{l}-0.111 * * * \\
(0.027)\end{array}$ \\
\hline$R^{2}$ & 0.37 & 0.29 & 0.57 & 0.35 & 0.27 & 0.53 \\
\hline$N$ & 220 & 121 & 99 & 220 & 121 & 99 \\
\hline
\end{tabular}


Table 4. Fixed Effects Panel Regression of US Investor Relative Weights, USD-denominated bonds The table presents panel regressions using annual data from 2006 through 2011. The sample is as specified in note to Table 3 with additional exclusion of Slovakia and Thailand for which we lack USD yield data. The dependent variable is U.S investors' normalized relative portfolio weight for each country's USD-denominated bonds. Each panel regression includes fixed destination-country effects. Standard errors (reported in parentheses) are clustered at the country level. Output for constants is not shown. See Table 3 for descriptions of explanatory variables. ${ }^{*} \mathrm{p}<0.1 ; * * \mathrm{p}<0.05 ; * * * \mathrm{p}<0.01$

\begin{tabular}{|c|c|c|c|c|c|c|}
\hline & $\begin{array}{c}\text { USDTotal All } \\
\text { (1) }\end{array}$ & $\begin{array}{l}\text { USDTotal AE } \\
\text { (2) }\end{array}$ & $\begin{array}{l}\text { USDTotal } \\
\text { EME } \\
\text { (3) }\end{array}$ & $\begin{array}{l}\text { USDTotal All } \\
\text { (4) }\end{array}$ & $\begin{array}{l}\text { USDTotal AE } \\
\text { (5) }\end{array}$ & $\begin{array}{l}\text { USDTotal } \\
\text { EME } \\
(6)\end{array}$ \\
\hline regcr & $\begin{array}{c}0.552 \\
(0.605)\end{array}$ & $\begin{array}{r}1.139 \\
(1.987)\end{array}$ & $\begin{array}{l}-0.027 \\
(0.174)\end{array}$ & $\begin{array}{l}0.564 \\
(0.649)\end{array}$ & $\begin{array}{l}1.571 \\
(2.495)\end{array}$ & $\begin{array}{r}0.022 \\
(0.173)\end{array}$ \\
\hline caopen & $\begin{array}{r}0.031 \\
(0.162)\end{array}$ & & $\begin{array}{r}0.119 \\
(0.095)\end{array}$ & $\begin{array}{r}0.121 \\
(0.130)\end{array}$ & & $\begin{array}{l}0.125^{*} \\
(0.068)\end{array}$ \\
\hline ca_gdp & $\begin{array}{r}0.470 \\
(0.712)\end{array}$ & $\begin{array}{r}0.654 \\
(1.518)\end{array}$ & $\begin{array}{l}1.132 * * \\
(0.434)\end{array}$ & $\begin{array}{r}0.372 \\
(0.658)\end{array}$ & $\begin{array}{r}0.326 \\
(1.336)\end{array}$ & $\begin{array}{l}1.122 * * \\
(0.454)\end{array}$ \\
\hline infvol & $\begin{array}{c}-7.944 * * * \\
(2.597)\end{array}$ & $\begin{array}{r}-8.432 \\
(6.590)\end{array}$ & $\begin{array}{l}-3.467 * \\
(1.617)\end{array}$ & $\begin{array}{c}-9.744 * * \\
(3.601)\end{array}$ & $\begin{array}{r}-12.654 \\
(9.960)\end{array}$ & $\begin{array}{l}-3.418^{* *} \\
(1.203)\end{array}$ \\
\hline usd_yld & $\begin{array}{l}-4.383 * \\
(2.563)\end{array}$ & $\begin{array}{c}-5.541^{*} \\
(2.906)\end{array}$ & $\begin{array}{r}2.424 \\
(1.799)\end{array}$ & $\begin{array}{l}-3.612^{*} \\
(2.017)\end{array}$ & $\begin{array}{l}-2.997^{*} \\
(1.490)\end{array}$ & $\begin{array}{r}1.213 \\
(1.373)\end{array}$ \\
\hline growth & $\begin{array}{l}-2.847 \\
(2.109)\end{array}$ & $\begin{array}{l}-5.630 \\
(5.331)\end{array}$ & $\begin{array}{r}0.267 \\
(0.571)\end{array}$ & $\begin{array}{l}-2.044 \\
(1.570)\end{array}$ & $\begin{array}{r}-2.852 \\
(3.610)\end{array}$ & $\begin{array}{l}-0.128 \\
(0.420)\end{array}$ \\
\hline 2007.year & $\begin{array}{r}8.178 \\
(9.489)\end{array}$ & $\begin{array}{c}15.772 \\
(15.651)\end{array}$ & $\begin{array}{r}-0.822 \\
(1.471)\end{array}$ & & & \\
\hline 2008.year & $\begin{array}{r}-1.862 \\
(5.730)\end{array}$ & $\begin{array}{r}-4.454 \\
(10.381)\end{array}$ & $\begin{array}{r}-3.136 \\
(2.408)\end{array}$ & & & \\
\hline 2009.year & $\begin{array}{r}-8.546 \\
(6.094)\end{array}$ & $\begin{array}{r}-19.407 \\
(15.050)\end{array}$ & $\begin{array}{r}0.752 \\
(3.694)\end{array}$ & & & \\
\hline 2010.year & $\begin{array}{r}-11.383 \\
(7.958)\end{array}$ & $\begin{array}{r}-23.629 \\
(16.624)\end{array}$ & $\begin{array}{r}8.058 \\
(5.317)\end{array}$ & & & \\
\hline 2011.year & $\begin{array}{c}-10.402^{*} \\
(6.049)\end{array}$ & $\begin{array}{c}-17.540^{*} \\
(9.793)\end{array}$ & $\begin{array}{r}9.617 \\
(5.773)\end{array}$ & & & \\
\hline USi10 & & & & $\begin{array}{l}5.019 \\
(3.673)\end{array}$ & $\begin{array}{l}6.233^{*} \\
(3.438)\end{array}$ & $\begin{array}{l}-4.388^{*} \\
(2.075)\end{array}$ \\
\hline LSAP_gdp & & & & $\begin{array}{r}-0.647 \\
(0.547)\end{array}$ & $\begin{array}{l}-0.900 \\
(0.767)\end{array}$ & $\begin{array}{l}-0.003 \\
(0.254)\end{array}$ \\
\hline vix_eoy & & & & $\begin{array}{c}0.403 \\
(0.430)\end{array}$ & $\begin{array}{r}0.487 \\
(0.493)\end{array}$ & $\begin{array}{l}-0.516^{* *} \\
(0.178)\end{array}$ \\
\hline$R^{2}$ & 0.11 & 0.15 & 0.55 & 0.10 & 0.11 & 0.53 \\
\hline$N$ & 199 & 115 & 84 & 199 & 115 & 84 \\
\hline
\end{tabular}


Table 5. Fixed Effects Panel Regression of US Investor Relative Weights, Local Currency Bonds with Private and Government Splits

The table presents panel regressions using annual data from 2007 through 2011. The sample is as specified in the note to Table 3 . The dependent variable is U.S investors' relative portfolio weight for each country's local currency bonds. Each panel regression includes fixed destination-country effects. Standard errors (reported in parentheses) are clustered at the country level. Output for constants is not shown. See Table 3 for descriptions of explanatory variables. ${ }^{*} \mathrm{p}<0.1 ; * * \mathrm{p}<0.05 ; * * * \mathrm{p}<0.01$

\begin{tabular}{|c|c|c|c|c|c|c|}
\hline & $\begin{array}{l}\text { LCGovt All } \\
\text { (1) }\end{array}$ & $\begin{array}{c}\text { LCGovt AE } \\
\text { (2) }\end{array}$ & $\begin{array}{l}\text { LCGovt EME } \\
\text { (3) }\end{array}$ & $\begin{array}{l}\text { LCpvt All } \\
\text { (4) }\end{array}$ & $\begin{array}{l}\text { LCpvt AE } \\
\text { (5) }\end{array}$ & $\begin{array}{c}\text { LCpvt EME } \\
\text { (6) }\end{array}$ \\
\hline regcr & $\begin{array}{c}0.078 \\
(0.179)\end{array}$ & $\begin{array}{l}-0.293 \\
(0.736)\end{array}$ & $\begin{array}{r}0.039 \\
(0.120)\end{array}$ & $\begin{array}{l}0.104 \\
(0.308)\end{array}$ & $\begin{array}{r}0.116 \\
(0.087)\end{array}$ & $\begin{array}{l}-0.268 \\
(0.442)\end{array}$ \\
\hline caopen & $\begin{array}{l}-0.098 \\
(0.088)\end{array}$ & & $\begin{array}{r}-0.042 \\
(0.117)\end{array}$ & $\begin{array}{r}0.069 \\
(0.542)\end{array}$ & & $\begin{array}{r}-0.019 \\
(0.503)\end{array}$ \\
\hline ca_gdp & $\begin{array}{r}0.015 \\
(0.436)\end{array}$ & $\begin{array}{l}-0.245 \\
(0.719)\end{array}$ & $\begin{array}{l}0.415^{*} \\
(0.230)\end{array}$ & $\begin{array}{l}-0.241 \\
(0.279)\end{array}$ & $\begin{array}{r}0.099 \\
(0.095)\end{array}$ & $\begin{array}{r}0.611 \\
(0.513)\end{array}$ \\
\hline infvol & $\begin{array}{r}-2.179 \\
(1.528)\end{array}$ & $\begin{array}{r}1.268 \\
(1.943)\end{array}$ & $\begin{array}{l}-2.611 * * \\
(1.179)\end{array}$ & $\begin{array}{r}0.834 \\
(1.784)\end{array}$ & $\begin{array}{r}-0.014 \\
(0.390)\end{array}$ & $\begin{array}{r}4.257 \\
(5.039)\end{array}$ \\
\hline yield & $\begin{array}{l}0.888 * \\
(0.473)\end{array}$ & $\begin{array}{r}0.670 \\
(0.946)\end{array}$ & $\begin{array}{r}0.702 \\
(0.419)\end{array}$ & $\begin{array}{r}1.841 \\
(1.702)\end{array}$ & $\begin{array}{r}-0.102 \\
(0.118)\end{array}$ & $\begin{array}{r}3.531 \\
(3.375)\end{array}$ \\
\hline growth & $\begin{array}{r}0.305 \\
(0.561)\end{array}$ & $\begin{array}{r}0.349 \\
(1.072)\end{array}$ & $\begin{array}{l}0.642^{*} \\
(0.366)\end{array}$ & $\begin{array}{r}1.761 \\
(1.472)\end{array}$ & $\begin{array}{r}-0.022 \\
(0.266)\end{array}$ & $\begin{array}{r}3.226 \\
(2.968)\end{array}$ \\
\hline 2008.year & $\begin{array}{r}-1.964 \\
(1.448)\end{array}$ & $\begin{array}{l}-6.280 * * * \\
(1.835)\end{array}$ & $\begin{array}{l}3.248^{* *} \\
(1.134)\end{array}$ & $\begin{array}{r}5.795 \\
(4.545)\end{array}$ & $\begin{array}{r}1.645 \\
(1.370)\end{array}$ & $\begin{array}{r}8.287 \\
(10.139)\end{array}$ \\
\hline 2009.year & $\begin{array}{r}3.389 \\
(2.677)\end{array}$ & $\begin{array}{r}-3.332 \\
(3.936)\end{array}$ & $\begin{array}{l}8.797 * * * \\
(2.259)\end{array}$ & $\begin{array}{r}6.638 \\
(5.383)\end{array}$ & $\begin{array}{r}0.885 \\
(0.582)\end{array}$ & $\begin{array}{r}7.427 \\
(7.958)\end{array}$ \\
\hline 2010.year & $\begin{array}{r}1.703 \\
(2.777)\end{array}$ & $\begin{array}{r}-5.592 \\
(4.030)\end{array}$ & $\begin{array}{l}8.375^{* * *} \\
(2.277)\end{array}$ & $\begin{array}{r}7.913 \\
(4.855)\end{array}$ & $\begin{array}{r}0.764 \\
(0.499)\end{array}$ & $\begin{array}{r}12.417 \\
(7.259)\end{array}$ \\
\hline 2011.year & $\begin{array}{c}2.472 \\
(2.260)\end{array}$ & $\begin{array}{r}-4.500 \\
(3.742)\end{array}$ & $\begin{array}{l}9.209 * * * \\
(2.375)\end{array}$ & $\begin{array}{l}9.944 \\
(7.594)\end{array}$ & $\begin{array}{l}1.118^{*} \\
(0.585)\end{array}$ & $\begin{array}{l}21.893 \\
(17.771)\end{array}$ \\
\hline$R^{2}$ & 0.11 & 0.16 & 0.37 & 0.06 & 0.08 & 0.11 \\
\hline$N$ & 178 & 100 & 78 & 178 & 100 & 78 \\
\hline
\end{tabular}


Table 6. Fixed Effects Panel Regression of US Investor Relative Weights, USD-denominated Bonds with Private and Government Splits

The table presents panel regressions using annual data from 2007 through 2011. The sample is as specified in the note to Table 3, with additional exclusion of Slovakia and Thailand for which USD yield data are not available. The dependent variable is U.S investors' relative portfolio weight for each country's USDdenominated bonds. Each panel regression includes fixed destination-country effects. Standard errors (reported in parentheses) are clustered at the country level. Output for constants is not shown. See Table 3 for descriptions of explanatory variables. $* \mathrm{p}<0.1 ; * * \mathrm{p}<0.05 ; * * * \mathrm{p}<0.01$

\begin{tabular}{|c|c|c|c|c|c|c|}
\hline & $\begin{array}{l}\text { USDGovt All } \\
\text { (1) }\end{array}$ & $\begin{array}{r}\text { USDGovt AE } \\
(2)\end{array}$ & $\begin{array}{r}\text { USDGovt EME } \\
\text { (3) }\end{array}$ & $\begin{array}{r}\text { USDpvt All } \\
\text { (4) }\end{array}$ & $\begin{array}{l}\text { USDpvt AE } \\
\end{array}$ & $\begin{array}{l}\text { USDpvt EME } \\
\text { (6) }\end{array}$ \\
\hline regcr & $\begin{array}{l}-2.048 \\
(2.440)\end{array}$ & $\begin{array}{r}-2.773 \\
(13.846)\end{array}$ & $\begin{array}{r}-0.637 \\
(0.946)\end{array}$ & $\begin{array}{r}-0.142 \\
(0.650)\end{array}$ & $\begin{array}{l}0.464 \\
(2.901)\end{array}$ & $\begin{array}{l}-0.516 \\
(0.331)\end{array}$ \\
\hline caopen & $\begin{array}{l}2.023 \\
(2.473)\end{array}$ & & $\begin{array}{c}0.144 \\
(0.592)\end{array}$ & $\begin{array}{r}-0.006 \\
(0.356)\end{array}$ & & $\begin{array}{r}0.013 \\
(0.327)\end{array}$ \\
\hline ca_gdp & $\begin{array}{r}0.885 \\
(5.545)\end{array}$ & $\begin{array}{r}-1.945 \\
(12.051)\end{array}$ & $\begin{array}{r}4.541 * * \\
(1.533)\end{array}$ & $\begin{array}{r}-0.113 \\
(0.614)\end{array}$ & $\begin{array}{c}0.199 \\
(1.220)\end{array}$ & $\begin{array}{l}0.451 \\
(1.690)\end{array}$ \\
\hline infvol & $\begin{array}{r}-13.901 \\
(17.695)\end{array}$ & $\begin{array}{r}-32.844 \\
(39.190)\end{array}$ & $\begin{array}{r}-20.419^{* *} \\
(6.638)\end{array}$ & $\begin{array}{r}-6.024 \\
(3.786)\end{array}$ & $\begin{array}{r}-4.493 \\
(3.902)\end{array}$ & $\begin{array}{r}-8.596 \\
(8.054)\end{array}$ \\
\hline usd_yld & $\begin{array}{l}14.923 \\
(16.811)\end{array}$ & $\begin{array}{l}32.026 \\
(30.829)\end{array}$ & $\begin{array}{r}18.528 * * * \\
(5.959)\end{array}$ & $\begin{array}{r}-0.547 \\
(2.336)\end{array}$ & $\begin{array}{r}-3.183^{*} \\
(1.584)\end{array}$ & $\begin{array}{r}6.800 \\
(6.926)\end{array}$ \\
\hline growth & $\begin{array}{l}13.983 \\
(18.736)\end{array}$ & $\begin{array}{l}52.621 \\
(56.709)\end{array}$ & $\begin{array}{c}0.602 \\
(3.598)\end{array}$ & $\begin{array}{r}-2.842 \\
(2.746)\end{array}$ & $\begin{array}{r}-5.156 \\
(5.562)\end{array}$ & $\begin{array}{r}-2.479 \\
(3.602)\end{array}$ \\
\hline 2008.year & $\begin{array}{r}-33.466 \\
(56.498)\end{array}$ & $\begin{array}{r}4.385 \\
(66.848)\end{array}$ & $\begin{array}{r}-19.532^{*} \\
(9.217)\end{array}$ & $\begin{array}{r}1.351 \\
(11.395)\end{array}$ & $\begin{array}{r}-14.431 \\
(13.276)\end{array}$ & $\begin{array}{l}22.861 \\
(22.084)\end{array}$ \\
\hline 2009.year & $\begin{array}{r}138.746 \\
(91.648)\end{array}$ & $\begin{array}{l}361.775 \\
(256.200)\end{array}$ & $\begin{array}{l}20.891 \\
(17.750)\end{array}$ & $\begin{array}{r}-12.241 \\
(11.803)\end{array}$ & $\begin{array}{r}-28.826 \\
(20.974)\end{array}$ & $\begin{array}{l}1.299 \\
(7.370)\end{array}$ \\
\hline 2010.year & $\begin{array}{r}88.414 \\
(104.177)\end{array}$ & $\begin{array}{l}307.893 \\
(278.912)\end{array}$ & $\begin{array}{l}-3.365 \\
(24.404)\end{array}$ & $\begin{array}{r}-16.261 \\
(15.004)\end{array}$ & $\begin{array}{r}-33.546 \\
(24.850)\end{array}$ & $\begin{array}{r}8.822 \\
(12.340)\end{array}$ \\
\hline 2011.year & $\begin{array}{l}43.136 \\
(68.316)\end{array}$ & $\begin{array}{l}198.499 \\
(182.888)\end{array}$ & $\begin{array}{r}-13.539 \\
(23.609)\end{array}$ & $\begin{array}{r}-12.738 \\
(11.655)\end{array}$ & $\begin{array}{r}-24.395 \\
(15.986)\end{array}$ & $\begin{array}{r}8.490 \\
(15.305)\end{array}$ \\
\hline$R^{2}$ & 0.07 & 0.11 & 0.65 & 0.07 & 0.13 & 0.15 \\
\hline$N$ & 134 & 74 & 60 & 152 & 95 & 57 \\
\hline
\end{tabular}




\section{Appendix Table 1. Bond Market Development}

Data on international bonds are built from data that underlie two BIS Quarterly Review tables, Table 14B (International Bonds and Notes by Country of Residence) and Table 16A (Domestic Debt Securities). Local-currency-denominated debt is the sum of the local currency portion of Table 14B and the long-term debt component from Table 16A. The country groupings follow IMF classifications of "advanced economies" and "other emerging market and developing economies" (shortened to emerging economies) as of April 2013. See http://www.imf.org/external/pubs/ft/weo/2013/01/pdf/statappx.pdf.

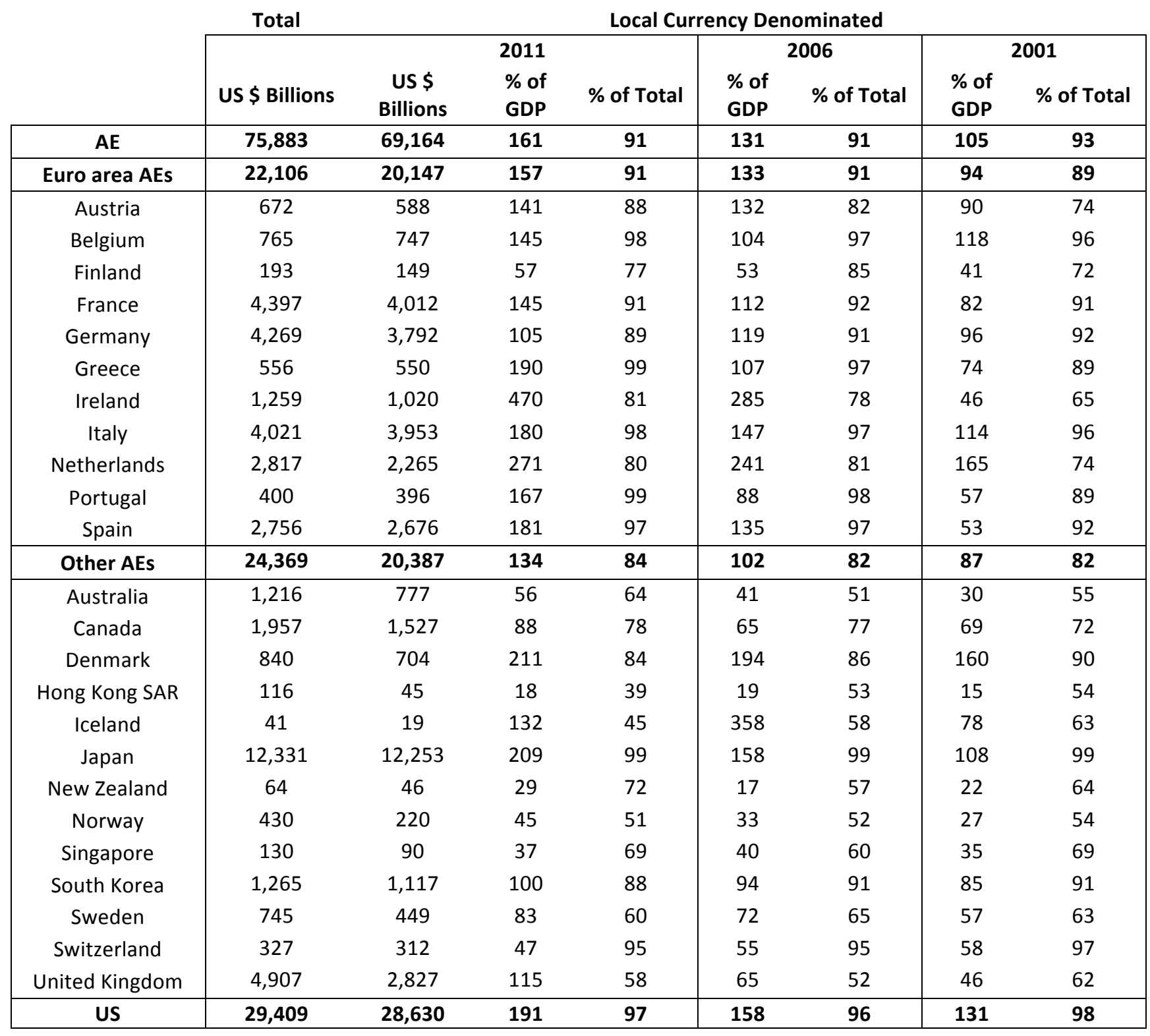


Appendix Table 1, continued. Bond Market Development

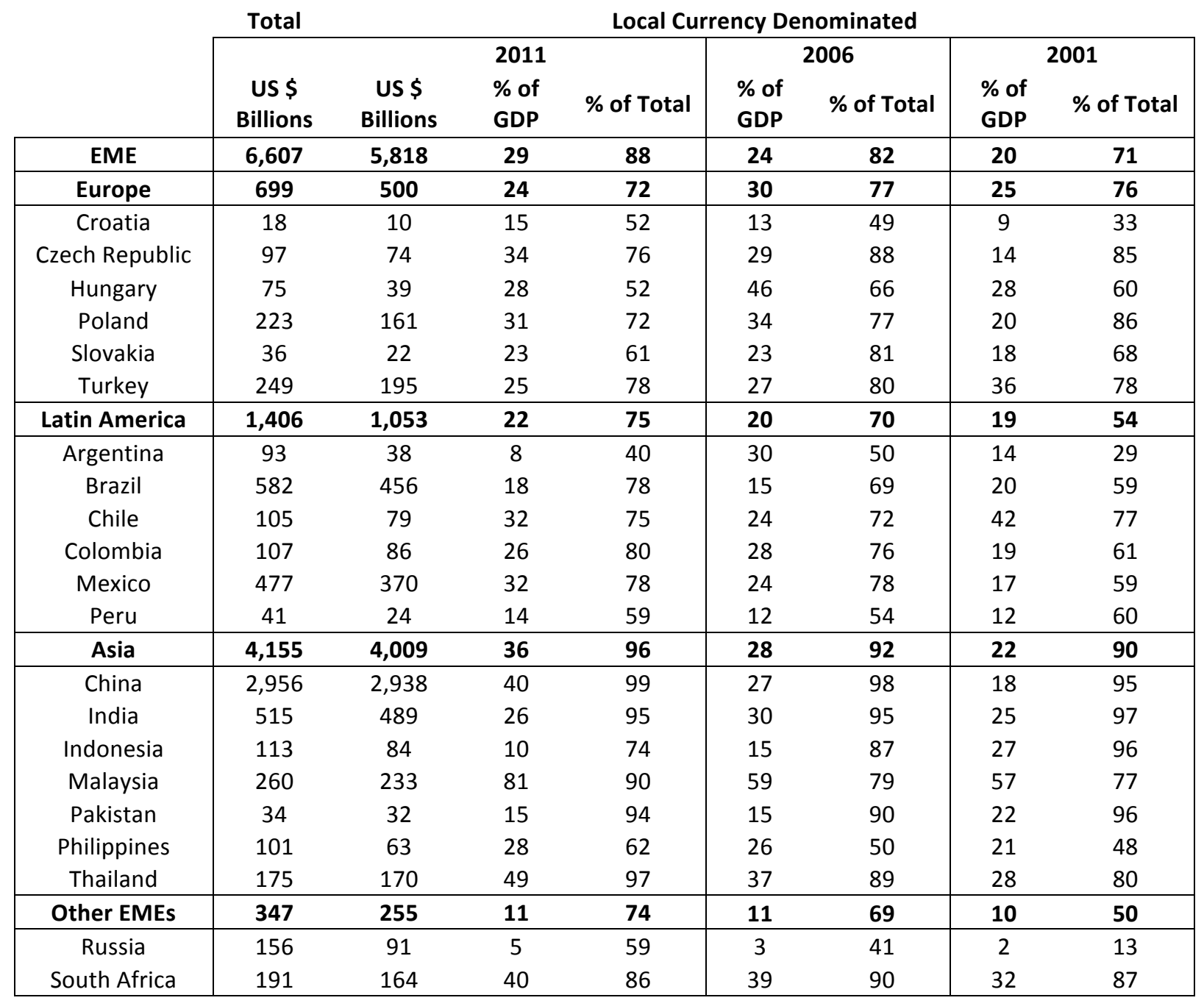




\section{Appendix Table 2. US Participation in Local Currency Bond Markets}

The table shows US investors' local currency bond portfolio as of the end of 2001, 2006, 2008, and 2011. Data are author's calculations using data on US investment from the US Department of the Treasury et al. (2002, 2007, 2009, and 2012) and the size of local currency bond markets (mostly from the BIS; see Table 1 for details). $\omega_{\text {US }}$ and $\omega_{\mathrm{mkt}}$ are the weight of the country in US and world market portfolios. The $\omega_{\mathrm{US}}$ to $\omega_{\mathrm{mkt}}$ ratio is a relative weight measure. It equals one if the weight of the countries' bonds in US and world market portfolios are identical and less than one if US investors' underweight the country (relative to its market size).

\begin{tabular}{|c|c|c|c|c|c|c|c|c|c|c|}
\hline & \multicolumn{4}{|c|}{2011} & \multicolumn{2}{|c|}{2008} & \multicolumn{2}{|c|}{2006} & \multicolumn{2}{|c|}{2001} \\
\hline & $\begin{array}{c}\text { US } \\
\text { Holdings } \\
\text { (\$ billions) }\end{array}$ & $\omega_{s}$ & $\omega_{n k t}$ & $\omega_{1 s} / \omega_{m k t}$ & $\begin{array}{c}\text { US } \\
\text { Holdings } \\
\text { (\$ billions) }\end{array}$ & $\omega_{1 s} / \omega_{n k t}$ & $\begin{array}{c}\text { US } \\
\text { Holdings } \\
\text { (\$ billions) }\end{array}$ & $\omega_{s s} / \omega_{m k t}$ & $\begin{array}{c}\text { US } \\
\text { Holdings } \\
\text { (\$ billions) }\end{array}$ & $\omega_{s} / \omega_{n k t}$ \\
\hline EME & 85.05 & 0.44 & 7.98 & 0.055 & 27.72 & 0.026 & 19.32 & 0.025 & 1.71 & 0.004 \\
\hline Europe & 16.95 & 0.09 & 0.69 & 0.127 & 4.55 & 0.034 & 4.72 & 0.038 & 0.74 & 0.012 \\
\hline CROATIA & 0.00 & 0.00 & 0.01 & 0.000 & 0.00 & 0.000 & 0.00 & 0.000 & 0.00 & 0.000 \\
\hline CZECH REPUBLIC & 0.19 & 0.00 & 0.10 & 0.010 & 0.04 & 0.002 & 0.01 & 0.001 & 0.01 & 0.003 \\
\hline HUNGARY & 3.26 & 0.02 & 0.05 & 0.317 & 1.52 & 0.082 & 0.62 & 0.037 & 0.17 & 0.027 \\
\hline POLAND & 13.24 & 0.07 & 0.22 & 0.309 & 2.89 & 0.070 & 3.83 & 0.100 & 0.55 & 0.034 \\
\hline SLOVAKIA & 0.19 & 0.00 & 0.03 & 0.032 & 0.00 & 0.000 & 0.24 & 0.047 & 0.00 & 0.000 \\
\hline TURKEY & 0.08 & 0.00 & 0.27 & 0.002 & 0.10 & 0.002 & 0.02 & 0.000 & 0.00 & 0.000 \\
\hline Latin America & 40.05 & 0.21 & 1.44 & 0.143 & 16.74 & 0.080 & 10.73 & 0.060 & 0.46 & 0.004 \\
\hline ARGENTINA & 0.36 & 0.00 & 0.05 & 0.035 & 0.34 & 0.020 & 2.39 & 0.114 & 0.07 & 0.005 \\
\hline BRAZIL & 20.11 & 0.10 & 0.63 & 0.166 & 8.48 & 0.106 & 4.72 & 0.090 & 0.08 & 0.002 \\
\hline CHILE & 0.97 & 0.00 & 0.11 & 0.046 & 0.01 & 0.001 & 0.00 & 0.000 & 0.01 & 0.001 \\
\hline COLOMBIA & 4.01 & 0.02 & 0.12 & 0.176 & 3.37 & 0.198 & 1.43 & 0.096 & 0.00 & 0.000 \\
\hline MEXICO & 13.31 & 0.07 & 0.51 & 0.135 & 3.99 & 0.052 & 2.08 & 0.028 & 0.29 & 0.006 \\
\hline PERU & 1.30 & 0.01 & 0.03 & 0.202 & 0.33 & 0.064 & 0.06 & 0.017 & 0.00 & 0.000 \\
\hline Asia & 19.76 & 0.10 & 5.50 & 0.019 & 5.18 & 0.008 & 2.77 & 0.007 & 0.06 & 0.000 \\
\hline CHINA & 0.31 & 0.00 & 4.03 & 0.000 & 0.20 & 0.000 & 0.01 & 0.000 & 0.00 & 0.000 \\
\hline INDIA & 0.34 & 0.00 & 0.67 & 0.003 & 0.01 & 0.000 & 0.00 & 0.000 & 0.00 & 0.000 \\
\hline INDONESIA & 5.83 & 0.03 & 0.12 & 0.261 & 1.85 & 0.111 & 1.08 & 0.062 & 0.00 & 0.000 \\
\hline MALAYSIA & 7.73 & 0.04 & 0.32 & 0.125 & 2.59 & 0.058 & 1.06 & 0.034 & 0.02 & 0.001 \\
\hline PAKISTAN & 0.00 & 0.00 & 0.04 & 0.000 & 0.00 & 0.000 & 0.00 & 0.000 & 0.00 & 0.000 \\
\hline PHILIPPINES & 3.97 & 0.02 & 0.09 & 0.237 & 0.05 & 0.004 & 0.04 & 0.004 & 0.01 & 0.001 \\
\hline THAILAND & 1.58 & 0.01 & 0.23 & 0.035 & 0.48 & 0.015 & 0.57 & 0.023 & 0.03 & 0.002 \\
\hline \multicolumn{11}{|l|}{ Other EMEs } \\
\hline RUSSIA & 0.66 & 0.00 & 0.12 & 0.027 & 0.10 & 0.008 & 0.02 & 0.001 & 0.00 & 0.002 \\
\hline SOUTH AFRICA & 7.34 & 0.04 & 0.23 & 0.168 & 0.91 & 0.034 & 1.04 & 0.031 & 0.44 & 0.028 \\
\hline
\end{tabular}


Appendix Table 2, continued. US Participation in Local Currency Bond Markets

\begin{tabular}{|c|c|c|c|c|c|c|c|c|c|c|}
\hline & \multicolumn{4}{|c|}{2011} & \multicolumn{2}{|c|}{2008} & \multicolumn{2}{|c|}{2006} & \multicolumn{2}{|c|}{2001} \\
\hline & $\begin{array}{c}\text { US } \\
\text { Holdings } \\
\text { (\$ billions) }\end{array}$ & $\omega_{s}$ & $\omega_{\mathrm{mkt}}$ & $\omega_{1 s} / \omega_{n k t}$ & $\begin{array}{c}\text { US } \\
\text { Holdings } \\
\text { (\$ billions) }\end{array}$ & $\omega_{1 s} / \omega_{m k t}$ & $\begin{array}{c}\text { US } \\
\text { Holdings } \\
\text { (\$ billions) }\end{array}$ & $\omega_{s} / \omega_{n k t}$ & $\begin{array}{c}\text { US } \\
\text { Holdings } \\
\text { (\$ billions) }\end{array}$ & $\omega_{1 s} / \omega_{n k t}$ \\
\hline $\mathbf{A E}$ & 408.66 & 2.11 & 55.87 & 0.038 & 268.89 & 0.027 & 247.12 & 0.03 & 150.33 & 0.028 \\
\hline Euro Area & 135.8 & 0.7 & 27.62 & 0.030 & 120.64 & 0.020 & 105.49 & 0.02 & 82.02 & 0.030 \\
\hline AUSTRIA & 1.48 & 0.01 & 0.81 & 0.009 & 0.80 & 0.005 & 1.20 & 0.01 & 0.75 & 0.010 \\
\hline BELGIUM & 3.25 & 0.02 & 1.02 & 0.016 & 4.58 & 0.024 & 3.37 & 0.02 & 2.77 & 0.024 \\
\hline FINLAND & 1.09 & 0.01 & 0.20 & 0.028 & 0.54 & 0.016 & 0.92 & 0.03 & 0.57 & 0.026 \\
\hline FRANCE & 27.32 & 0.14 & 5.50 & 0.026 & 27.86 & 0.028 & 29.93 & 0.04 & 14.70 & 0.031 \\
\hline GERMANY & 52.30 & 0.27 & 5.20 & 0.052 & 55.12 & 0.047 & 38.63 & 0.03 & 38.15 & 0.050 \\
\hline GREECE & 0.78 & 0.00 & 0.75 & 0.005 & 0.81 & 0.007 & 1.14 & 0.01 & 1.38 & 0.033 \\
\hline IRELAND & 10.91 & 0.06 & 1.40 & 0.040 & 5.25 & 0.016 & 5.90 & 0.03 & 0.49 & 0.024 \\
\hline ITALY & 16.52 & 0.09 & 5.42 & 0.016 & 8.86 & 0.008 & 6.18 & 0.01 & 9.55 & 0.018 \\
\hline NETHERLANDS & 15.23 & 0.08 & 3.11 & 0.025 & 12.77 & 0.021 & 14.29 & 0.03 & 7.82 & 0.028 \\
\hline PORTUGAL & 0.44 & 0.00 & 0.54 & 0.004 & 0.24 & 0.003 & 0.30 & 0.01 & 0.16 & 0.006 \\
\hline SPAIN & 6.50 & 0.03 & 3.67 & 0.009 & 3.80 & 0.005 & 3.63 & 0.01 & 5.68 & 0.041 \\
\hline Other AEs & 272.86 & 1.41 & 28.25 & 0.050 & 148.25 & 0.032 & 141.63 & 0.04 & 68.31 & 0.020 \\
\hline AUSTRALIA & 26.87 & 0.14 & 1.07 & 0.130 & 7.75 & 0.077 & 6.20 & 0.06 & 3.26 & 0.068 \\
\hline CANADA & 102.85 & 0.53 & 2.09 & 0.253 & 44.24 & 0.157 & 39.99 & 0.15 & 21.48 & 0.103 \\
\hline DENMARK & 1.50 & 0.01 & 0.97 & 0.008 & 7.98 & 0.040 & 8.36 & 0.05 & 2.27 & 0.021 \\
\hline HONG KONG & 1.35 & 0.01 & 0.06 & 0.114 & 0.26 & 0.021 & 0.25 & 0.02 & 0.07 & 0.007 \\
\hline ICELAND & 0.54 & 0.00 & 0.03 & 0.109 & 1.28 & 0.262 & 0.34 & 0.02 & 0.00 & 0.000 \\
\hline JAPAN & 50.19 & 0.26 & 16.80 & 0.015 & 49.67 & 0.017 & 39.41 & 0.02 & 21.35 & 0.011 \\
\hline NEW ZEALAND & 4.34 & 0.02 & 0.06 & 0.357 & 1.28 & 0.246 & 1.75 & 0.29 & 1.29 & 0.263 \\
\hline NORWAY & 7.04 & 0.04 & 0.30 & 0.120 & 1.48 & 0.040 & 2.06 & 0.06 & 0.41 & 0.021 \\
\hline SINGAPORE & 5.54 & 0.03 & 0.12 & 0.232 & 1.59 & 0.066 & 2.48 & 0.14 & 0.04 & 0.003 \\
\hline SOUTH KOREA & 12.95 & 0.07 & 1.53 & 0.044 & 3.43 & 0.014 & 2.32 & 0.01 & 0.25 & 0.001 \\
\hline SWEDEN & 7.36 & 0.04 & 0.62 & 0.062 & 3.61 & 0.038 & 6.42 & 0.07 & 3.66 & 0.066 \\
\hline SWITZERLAND & 1.65 & 0.01 & 0.43 & 0.020 & 1.02 & 0.012 & 0.25 & 0.00 & 0.11 & 0.002 \\
\hline UNITED KINGDOM & 48.40 & 0.25 & 3.88 & 0.064 & 23.50 & 0.040 & 30.39 & 0.06 & 13.51 & 0.047 \\
\hline
\end{tabular}

